This document is the Accepted Manuscript version of a Published Work that appeared in final form in Inorganic Chemistry, copyright (C) American Chemical Society after peer review and technical editing by the publisher.

To access the final edited and published work see Inorganic Chemistry 2017, 56(6), 3674-3685

\title{
https://doi.org/10.1021/acs.inorgchem.7b00075
}

Also see same web-link for Supporting Information, available free of charge. 


\title{
Phenanthridine-Containing Pincer-like Amido
}

\section{Complexes of Nickel, Palladium and Platinum}

\author{
Pavan Mandapati, ${ }^{a}$ Patrick K. Giesbrecht, ${ }^{a}$ Rebecca L. Davis, ${ }^{a}$ David E. Herbert ${ }^{a *}$ \\ ${ }^{a}$ Department of Chemistry and the Manitoba Institute for Materials, University of Manitoba, 144 \\ Dysart Rd, Winnipeg, MB, Canada, R3T 2N2
}


ABSTRACT: Proligands based on bis(8-quinolinyl)amine (L1) were prepared containing one (L2) and two (L3) benzo-fused $N$-heterocyclic phenanthridinyl (3,4-benzoquinolinyl) units. Taken as a series, L1-L3 provides a ligand template for exploring systematic $\pi$-extension in the context of tridentate pincer-like amido complexes of Group 10 metals (1-M, 2-M and 3-M; $\mathbf{M}=$ $\mathrm{Ni}, \mathrm{Pd}, \mathrm{Pt}$ ). Inclusion of phenanthridinyl units was enabled by development of a crosscoupling/condensation route to 6-unsubstituted, 4-substituted phenanthridines $\left(4-\mathrm{Br}, 4-\mathrm{NO}_{2}, 4\right.$ $\mathbf{N H}_{2}$ ) suitable for elaboration into the target ligand frameworks. Complexes 1-M, 2-M and 3-M are redox-active; electrochemistry and UV-Vis absorption spectroscopy were used to investigate the impact of $\pi$-extension on the electronic properties of the metal complexes. Unlike what is typically observed for benzannulated ligand-metal complexes, extending the $\pi$-system in metal complexes 1-M to 2-M to 3-M led to only a moderate red shift in the relative HOMO-LUMO gap as estimated by electrochemistry, and similarly subtle changes to the onset of the lowest energy absorption observed by UV-Vis spectroscopy. TD-DFT revealed that benzannulation significantly impacts the atomic contributions to the LUMO and LUMO+1 orbitals, altering the orbital contributions to the lowest energy transition but leaving the energy of this transition essentially unchanged. 


\section{INTRODUCTION}

Extending the $\pi$-system of conjugated ligands is widely used to tune electronic transitions in transition metal $^{1}$ and main-group ${ }^{2}$ complexes without significantly altering the parent ligand framework. This can provide important flexibility in the design of new emissive molecules and photosensitizers, as photophysical properties can be adjusted without wholesale changes to the core molecular shape. Furthermore, as exemplified by a published series of (BPI)PtCl $(\mathrm{BPI}=$ bis(2-pyridylimino)isoindolate) complexes, red or blue shifts are both possible with increasing $\pi$ extension. The direction of the shift was rationalized by establishing how the site of benzannulation impacts the energies of the frontier orbitals (HOMO/LUMO). ${ }^{1 \mathrm{~d}}$

In this context, tridentate pincer-type ligands containing benzannulated aromatic $\mathrm{N}$ heterocycles offer the potential to form robust complexes bearing an electronically accessible extended $\pi$-system. ${ }^{3}$ The benzannulated aromatic $N$-heterocycle phenanthridine (3,4benzoquinoline) is much less well-known as a ligand than its more symmetric isomer acridine (2,3-benzoquinoline),${ }^{4}$ the readily cyclometallated benzo[h]quinoline $(7,8 \text {-benzoquinoline })^{5}$ and quinoline itself (2,3-benzopyridine). This is despite phenanthridine's utility in fluorescent DNA intercalators such as ethidium bromide ${ }^{6}$ and related emissive organic materials, ${ }^{7}$ in platin drug candidates (phenathriplatin: cis- $\left[\mathrm{Pt}\left(\mathrm{NH}_{3}\right)_{2}\right.$ (phenanthridine) $\left.\left.\mathrm{Cl}\right] \mathrm{NO}_{3}\right),{ }^{8}$ and as a co-catalyst in hydrogenation reactions. ${ }^{9}$ To our knowledge, only a handful of multi-dentate ligands that bring phenanthridinyl units into the coordination sphere of metals are known. Emissive tris(4phenanthridinolato)lithium and aluminum complexes have been used in electroluminescent devices. ${ }^{10}(R)$ and $(S)$-6-(2'-diphenylphosphino-l'-naphthyl)phenanthridines were applied as atropisomeric ligands in Pd-catalyzed allylic alkylations. ${ }^{11}$ Fac-binding, tridentate bis(phenanthridinylmethyl)amines bound to $\operatorname{Re}(\mathrm{I})$ carbonyls have been used for live-cell 
fluorescence imaging. ${ }^{12}$ Chelate-assisted $\mathrm{C}-\mathrm{H}$ activation of substituted 6-arylphenanthridines has been used to generate luminescent $\mathrm{C}, \mathrm{N}$-cyclometalated phenanthridine-containing platinum(II) ${ }^{13}$ and deep-red emitting iridium(III) complexes. ${ }^{14}$ We have reported the preparation of (4diphenylphosphino)phenanthridine analogs of (8-diphenylphosphino)quinolines that can be used to form luminescent $\mathrm{Cu}$ and $\mathrm{Zn}$ coordination compounds. ${ }^{15}$

In this work, we present a synthetic route to tridentate phenanthridine-containing ligand frameworks based on bis(8-quinolinyl)amine (L1; Figure 1). ${ }^{16}$ Once deprotonated, these compounds $(\mathbf{L 2}, \mathbf{L 3})$ are capable of binding as monoanionic $\{\mathrm{NNN}\}$ - amido ligands, ${ }^{17}$ and therefore present an opportunity to investigate the coordination chemistry of phenanthridinecontaining 'pincer-type' ligands with divalent Group 10 metal ions. The resultant complexes allowed us to evaluate the impact of sequential quinoline-to-phenanthridine $\pi$-extension on their electronic properties, which we reasoned would be substantial given that benzannulation sitedependent red shifts of $10 \mathrm{~nm}$ and blue shifts of nearly $50 \mathrm{~nm}$ of the lowest energy absorption were observed in related series of $\pi$-extended ligand-metal complexes. ${ }^{1 \mathrm{~d}}$ Contrary to our initial hypothesis, while significant shifts are observed in the absorption spectra of $\mathbf{L 1}, \mathbf{L 2}$ and $\mathbf{L 3}$, the impact of $\pi$-system extension proved to be much more subtle in the Group 10 metal complexes 1-M, 2-M, 3-M (M = Ni, Pd, Pt). 


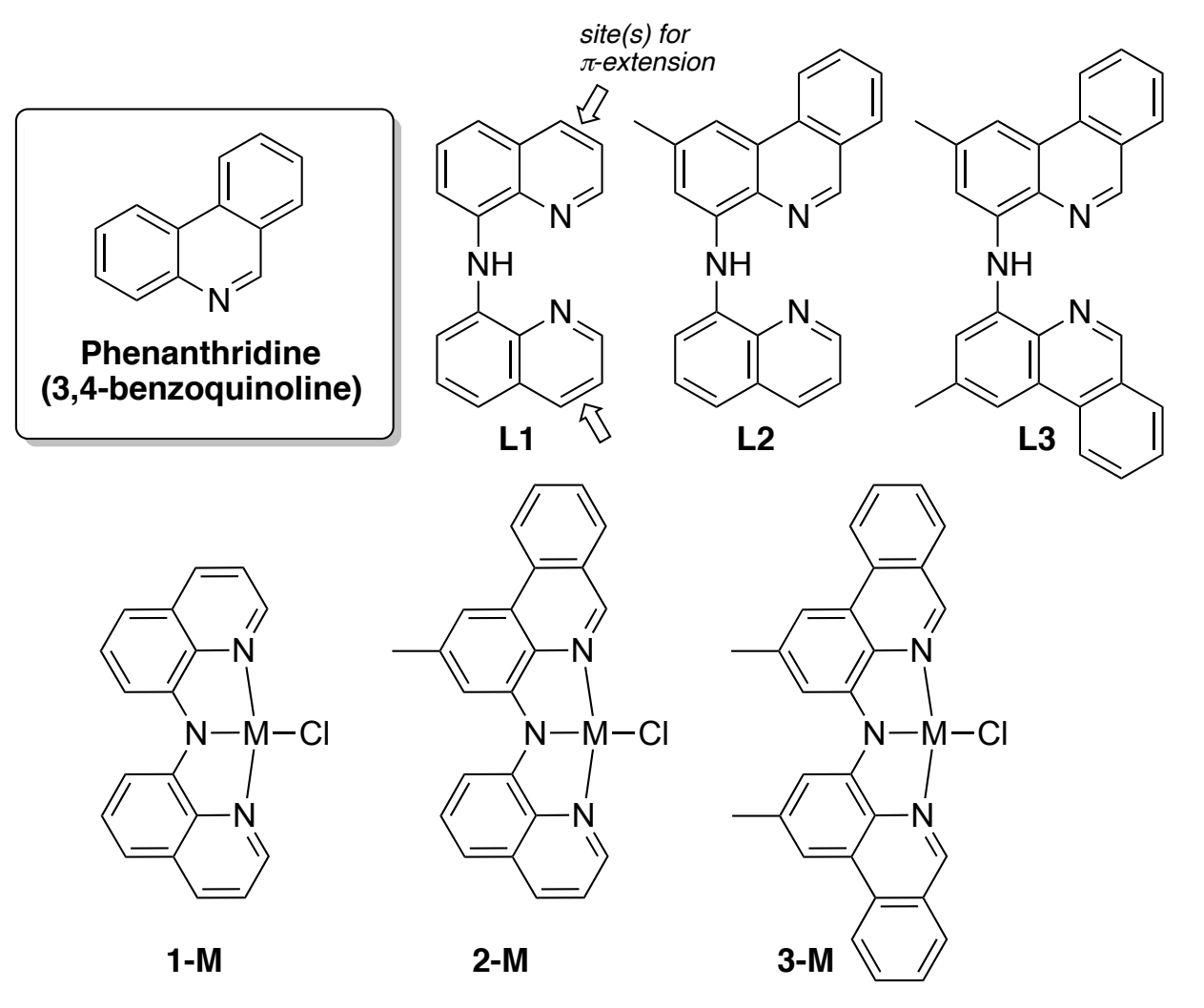

Figure 1. Proligands bis(8-quinolinyl)amine (L1), (4-methylphenanthridinyl)(8quinolinyl)amine (L2), bis(4-methylphenanthridinyl)amine (L3), and Group 10 metal complexes (1-M, 2-M and 3-M; $\mathbf{M}=\mathrm{Ni}, \mathrm{Pd}, \mathrm{Pt}$ ) discussed in this work.

\section{RESULTS AND DISCUSSION}

Bis(8-quinolinyl)amine (L1) provides two equivalent conceptual sites for $\pi$-extension to phenanthridinyl analogs (Figure 1). We decided to adapt Peters' cross-coupling methodology ${ }^{16 c}$ for the synthesis of $\mathbf{L} \mathbf{2}-\mathbf{L} \mathbf{3}$ and so first established a general preparative route to 4-substituted halo- and aminophenanthridines by combining $\mathrm{C}-\mathrm{C}$ and $\mathrm{C}-\mathrm{N}$ bond formation in a one-pot, $\mathrm{Pd}-$ catalyzed cross-coupling/condensation of substituted anilines with 2-formylphenylboronic acid (Figure 2a, Table S1). ${ }^{18}$ Phenanthridines lacking substituents in the 6-position are less common 
than 6-subsituted analogs, due to the electrophilic reactivity of the carbon at this position. ${ }^{19}$ Using para-substituted 2-bromo-6-iodo-4-methylaniline, we achieved higher isolated yields (> $90 \%$ ) of 4-bromo-2-methylphenanthridine (4-Br) compared with the analogous preparation of 4bromophenanthridine from 2,6-dibromoaniline (isolated yields $\sim 35 \%$ ), ${ }^{15}$ as the iodoarene can be easily prepared and is more active in cross-coupling. Direct coupling of 2-formylphenyl boronic acid with 1,2-diamino-6-iodo-toluene gave only moderate conversions ( $50 \%$ by NMR) to 4$\mathbf{N H}_{2}$, likely due to coordination of the aminophenanthridine to Pd. However, 2-methyl-4nitrophenanthridine $\left(4-\mathrm{NO}_{2}\right)$ was readily obtained from 2-bromo-6-nitro-4-methylaniline, and reduction of 4-NO $\mathbf{O}_{2}$ with $\mathrm{Zn} / \mathrm{NH}_{2}-\mathrm{NH}_{2}$ and formic acid allowed isolation of $\mathbf{4}-\mathbf{N H}_{2}$ in good yield (> $85 \%$, Figure $2 \mathrm{~b}$ ). With the 4-substituted phenanthridines in hand, forcing conditions $\left[150{ }^{\circ} \mathrm{C}\right.$, $72 \mathrm{~h} ; 5 \mathrm{~mol} \% \mathrm{Pd}(\mathrm{OAc})_{2}$, (1,1'-diphenylphosphino)ferrocene (dppf); sodium-tert-pentoxide] gave high isolated yields (>90\%) of both the asymmetric (4-methylphenanthridinyl)(8quinolinyl)amine (L2; Figure 2c), and the symmetric bis(4-methylphenanthridinyl)amine (L3; Figure 2d). 
(a)

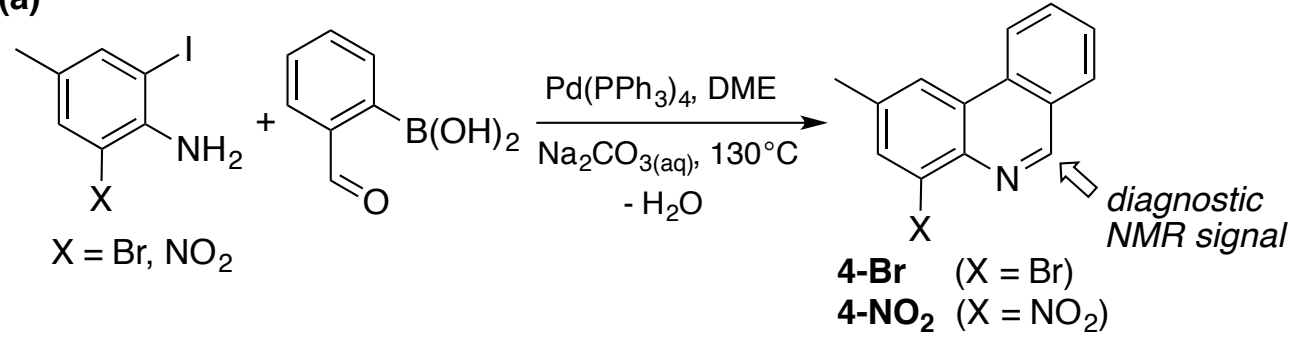

(b)<smiles>Cc1cc([N+](=O)[O-])c2ncc3ccccc3c2c1</smiles>

$\mathrm{Zn}, \mathrm{H}_{2} \mathrm{NNH}_{2} \cdot \mathrm{H}_{2} \mathrm{O} / \mathrm{HCO}_{2} \mathrm{H}$

$4-\mathrm{NO}_{2}$<smiles>Cc1cc(N)c2ncc3ccccc3c2c1</smiles>

(c)

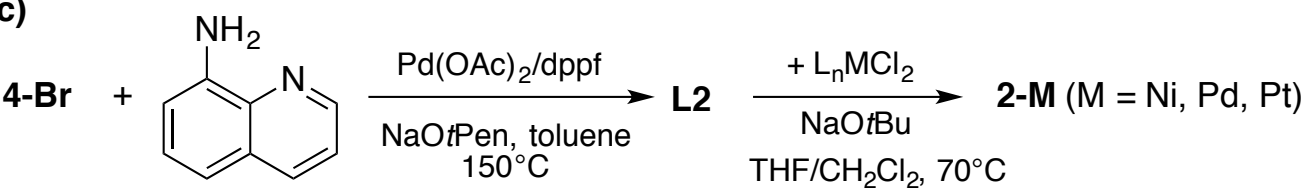

(d)

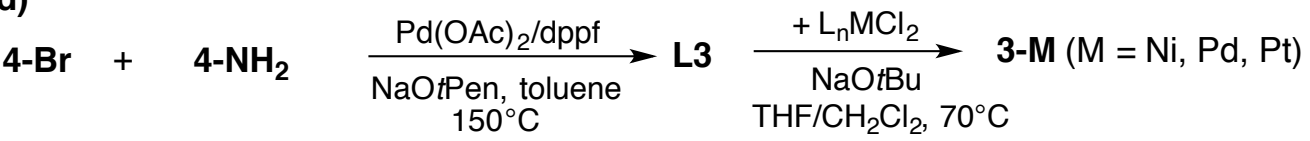

Figure 2. (a) One-pot Pd-catalyzed coupling/condensation route to 4-substituted phenanthridines (4-Br/4-NO $\mathrm{N}_{2}$; (b) reduction of $4-\mathrm{NO}_{2}$ to $4-\mathrm{NH}_{2}$; (c) synthesis of $\pi$-extended pincer-type proligand $\mathbf{L} \mathbf{2}$ and metal complexes 2-M; (c) synthesis of $\mathbf{L 3}$ and metal complexes 3-M $\left(\mathrm{L}_{\mathrm{n}} \mathrm{MCl}_{2}\right.$ $=\mathrm{NiCl}_{2}\left(\mathrm{H}_{2} \mathrm{O}\right)_{6},(1,5-\mathrm{COD}) \mathrm{PdCl} l_{2}$ or $\left.(1,5-\mathrm{COD}) \mathrm{PtCl}_{2}\right)$.

Both L2 and L3 show spectroscopic features diagnostic of phenanthridine groups (Table 1). The downfield shift of the ${ }^{1} \mathrm{H}$ and ${ }^{13} \mathrm{C}$ NMR resonances attributed to the $[\mathrm{CH}]$ unit in the 6position adjacent to the nitrogen in the phenanthridinyl ring system is consistent with a dominant 'imine-bridged, biphenyl' resonance contributor, which maximizes the number of aromatic subunits in accordance with Clar's postulate..$^{20}$ Accordingly, the solid-state X-ray structures of 
$\mathbf{L 2}$ and $\mathbf{L 3}$ show one short $\mathrm{C}=\mathrm{N}$ distance in each phenanthridine unit [L2: $\mathrm{N}(1)-\mathrm{C}(1)$ 1.298(2); L3: N(1)-C(1) 1.305(4), N(3)-C(15) 1.307(3) Å; Figure 3].

Table 1. Selected solution NMR data (diagnostic $[\mathrm{CH}]$ resonances; Figure 2) for L1-L3 and 1M/2-M/3-M (from reference ${ }^{16 c}$ and this work).

\begin{tabular}{|c|c|c|c|c|c|c|c|c|c|c|c|c|}
\hline & L1 & L2 & L3 & 1-Ni & 1-Pd & 1-Pt & 2-Ni & 2-Pd & 2-Pt & 3-Ni & 3-Pd & 3-Pt \\
\hline $\begin{array}{c}\delta\left({ }^{1} \mathrm{H}\right) \\
\mathrm{C}_{6}-H \\
\mathrm{pppm}\end{array}$ & 8.97 & 9.27 & 9.29 & 8.66 & 8.95 & 9.14 & 9.05 & 9.27 & 9.49 & 9.10 & 9.38 & 9.58 \\
\hline $\begin{array}{c}\left.\delta{ }^{(3)} \mathrm{C}\right) \\
C_{6}-\mathrm{H} / \\
\mathrm{ppm}\end{array}$ & 148.1 & 150.1 & 150.1 & 150.6 & 149.5 & 148.8 & 154.1 & 151.8 & 151.1 & 154.0 & 151.8 & 151.0 \\
\hline
\end{tabular}

No significant changes to the pseudo $C_{2 \mathrm{v}}$ symmetric ${ }^{1} \mathrm{H}$ NMR spectrum of $\mathbf{L} \mathbf{3}$ in $\mathrm{CD}_{2} \mathrm{Cl}_{2}$ were observed on cooling from $25{ }^{\circ} \mathrm{C}$ to $-90{ }^{\circ} \mathrm{C}$, implying that there is no significant barrier to the compound adopting a planar configuration, though in the solid-state $\mathbf{L 3}$ adopts a non-planar structure (dihedral angle between the two phenanthridinyl units $=31.1^{\circ}$ ). In comparison, the dihedral angle between phenanthridinyl and quinolinyl units observed in the solid-state structure of $\mathbf{L 2}$ is considerably smaller (3.4; Figure 3). 

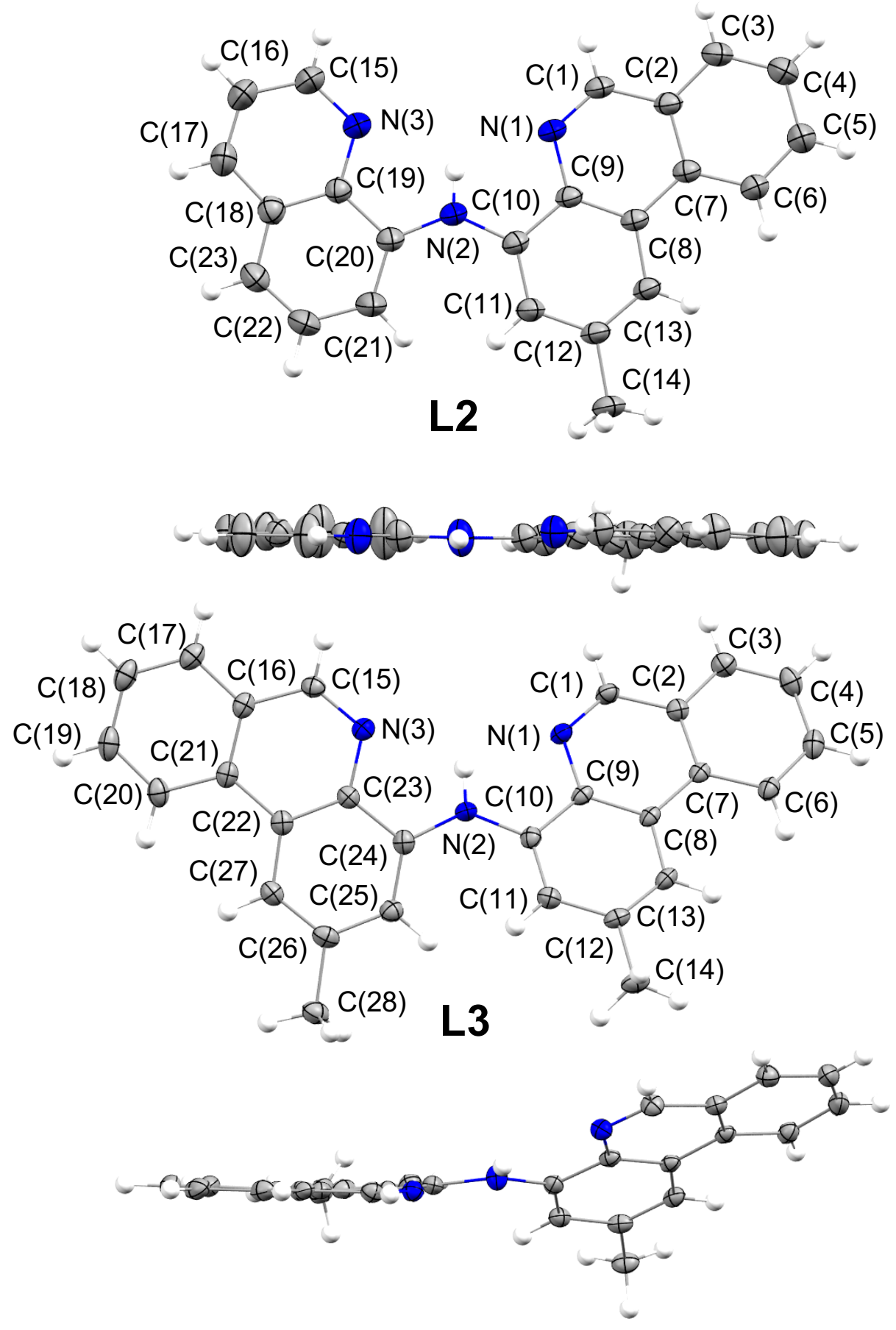

Figure 3. ORTEPs ${ }^{21}$ of $\mathbf{L 2}$ and $\mathbf{L 3}$, with thermal ellipsoids shown at 30\% (L2) and 50\% (L3) probability levels. For each structure, two views are shown. Selected bond distances ( $\AA$ ) for $\mathbf{L 2}$ : C(1)-N(1) 1.298(2), C(9)-N(1) 1.3811(17), C(9)-C(8) 1.4068(19), C(8)-C(7) 1.4444(19), C(2)$\mathrm{C}(1)$ 1.426(2), $\mathrm{C}(2)-\mathrm{C}(7)$ 1.4127(18), $\mathrm{C}(15)-\mathrm{N}(3)$ 1.319(2); and L3: $\mathrm{C}(1)-\mathrm{N}(1)$ 1.305(4), $\mathrm{C}(9)-$ 
$\mathrm{N}(1)$ 1.382(3), C(1)-C(2) 1.432(4), C(2)-C(7) 1.410(3), C(7)-C(8) 1.448(4), C(8)-C(9) 1.410(3), $\mathrm{C}(15)-\mathrm{N}(3)$ 1.307(3), C(23)-N(3) 1.385(3), C(15)-C(16) 1.428(4), C(16)-C(21) 1.413(4), C(21)$\mathrm{C}(22) 1.447(3), \mathrm{C}(22)-\mathrm{C}(23) 1.412(3)$.

$\mathbf{L 2}$ and $\mathbf{L 3}$ bear two $\mathrm{sp}^{2}$-hybridized, hard $\mathrm{N}$ donors and, on deprotonation, a diarylamido Lewis basic site. $\mathbf{L} \mathbf{1}$ has a similar donor set and as might be expected from this rigid donor core, binds to Group $8,{ }^{22}$ Group $9,{ }^{16 \mathrm{~d}}$ divalent Group $10,{ }^{16 \mathrm{c}} \mathrm{Cu}(\mathrm{II})^{16 \mathrm{~b}}$ and $\mathrm{Zn}(\mathrm{II})^{16 \mathrm{~d}}$ ions in a planar, meridional fashion. Facial binding, however, was also shown to be possible in an octahedral Pt(IV) complex. ${ }^{23} \mathbf{L} \mathbf{2}$ and $\mathbf{L} \mathbf{3}$ provide an opportunity to assess the impact of benzannulation on the donor strength of the $\mathrm{N}$-heterocyclic arms. The donor ability of pyridine toward the Lewis acid $\mathrm{BCl}_{3}$ is in between that of quinoline and acridine, ${ }^{24}$ consistent with the order of their $\mathrm{p} K_{\mathrm{a}}$ 's (quinoline $<$ pyridine $<$ acridine). Phenanthridine has a similar $\mathrm{p} K_{\mathrm{a}}$ to acridine (5.58), implying a similar 'donor strength' toward $\mathrm{H}^{+}$. With larger Lewis acids, phenanthridine (3,4benzoquinoline) should be less sterically encumbered than acridine (2,3-benzoquinoline), due to the asymmetry of benzannulation. To compare the coordination chemistry of our phenanthridinecontaining ligands $\mathbf{L} \mathbf{2}$ and $\mathbf{L 3}$ with that of $\mathbf{L 1}$, we targeted halide complexes of the Group 10 triad, as the analogous complexes of $\mathbf{L 1}(\mathbf{1 - M})$ are known. ${ }^{16 c}$

Divalent nickel, palladium and platinum complexes of L1-L3 were prepared in 65-89\% yields from reaction with the appropriate metal chloride salt in the presence of a base $(\mathrm{NaO} t \mathrm{Bu})$ in hot THF or $\mathrm{CH}_{2} \mathrm{Cl}_{2}$. Benzannulation decreases solubility, which was found to be generally poor in organic solvents for all complexes despite introduction of methyl groups to the $\mathrm{N}$-heterocyclic arms in $\mathbf{L} \mathbf{2}$ and $\mathbf{L 3}$, with metal complexes of $\mathbf{L 2}-\mathbf{L 3}$ precipitating from solution over the course of the reaction. Coordination of the proligands was followed by the shift of the diagnostic NMR spectroscopic resonances of the $[\mathrm{CH}]$ unit in the 6-position of the phenanthridinyl arms of $\mathbf{L 2}$ 
and $\mathbf{L 3}$ (Table 1). Coordination of $\mathbf{L} \mathbf{2}$ in $\mathbf{2}-\mathbf{N i}$ results in shifts of the signals for the $\left[\mathrm{C}_{6}-\mathrm{H}\right]$ unit to $9.05\left({ }^{1} \mathrm{H}, \mathrm{CDCl}_{3}\right)$ and $154.1 \mathrm{ppm}\left({ }^{13} \mathrm{C}\left\{{ }^{1} \mathrm{H}\right\}\right)$, with the equivalent resonances in 2-Pt observed at 9.49 and $151.1 \mathrm{ppm}$. In comparison, the same signals in 2-Pd are only slightly different from those of the free amine $\left(9.27 \mathrm{ppm}\right.$ and $151.8 \mathrm{ppm} ; c f . \mathbf{1 - N i}{ }^{1} \mathrm{H} 8.66,{ }^{13} \mathrm{C}\left\{{ }^{1} \mathrm{H}\right\} 150.6 \mathrm{ppm} ; \mathbf{1}-\mathbf{P d}$ : ${ }^{1} \mathrm{H} 8.95,{ }^{13} \mathrm{C}\left\{{ }^{1} \mathrm{H}\right\} 149.5$ ppm; 1-Pt: ${ }^{1} \mathrm{H} 9.14,{ }^{13} \mathrm{C}\left\{{ }^{1} \mathrm{H}\right\} 148.8$ ppm). ${ }^{16 c}$ For 3-M, the same trend is observed, with increasing deshielding of the diagnostic ${ }^{1} \mathrm{H}$ NMR resonance going down the group; the $\mathrm{C}_{6}-H$ proton signal resonates at $9.10(\mathbf{3}-\mathbf{N i}), 9.38$ (3-Pd) and $9.58 \mathrm{ppm}(\mathbf{3}-\mathbf{P t})$. No exchange is seen with free ligand in solution. The diagnostic spectroscopic signatures confirm stable complexation.

Slow diffusion of diethylether into chloroform solutions of $\mathbf{2}-\mathbf{M}$ or $\mathbf{3}-\mathbf{M}(\mathrm{M}=\mathrm{Ni}, \mathrm{Pd}, \mathrm{Pt})$ afforded single-crystals suitable for X-ray diffraction. In each case, high quality single-crystals with long-range order were obtained as a $\mathrm{CHCl}_{3}$-solvate. The metal complexes of $\mathbf{L 2}(\mathbf{2}-\mathbf{M})$ and L3 (3-M) are isostructural with previously reported structures of 1-Ni, 1-Pd and 1-Pt (Figure 4). ${ }^{16 c}$ In each structure, the three nitrogen donor atoms of the ligands are coplanar with the coordinated metal atom, with $\mathrm{M}-\mathrm{Cl}$ distances increasing with the size of the divalent metal ion (Table 2). The trans influence of the amido $\mathbf{N}$ donor in $\mathbf{L 1}$ was previously suggested to be minimal, as the amido $\mathrm{N}$ was found to bind selectively trans-disposed to strong trans influence alkyls/hydrides when a cis disposition was possible..$^{22}$ Direct comparison of trans influence of the amido $\mathrm{N}$ in $\mathbf{2}-\mathbf{M} / \mathbf{3}-\mathbf{M}$ to $\mathbf{1 - M}$ through solid-state $\mathrm{M}-\mathrm{Cl}$ bond distances is complicated by the presence of close-contacts between $\mathrm{CHCl}_{3}$ and the chloride ligand in the crystal lattice of 2-M and 3-M. Complexes of the two phenanthridine-containing ligands (2-M, 3-M) show statistically indistinguishable $\mathrm{M}-\mathrm{Cl}$ bond distances, consistent with similar trans influences of the amido $\mathrm{N}$ in $\mathbf{L} 2$ and $\mathbf{L 3}$. 
The trans influence of phenanthridine as a ligand can be thought of as similar to that of pyridine; statistically indistinguishable $\mathrm{Pt}-\mathrm{N}$ bond distances were reported trans to the $\mathrm{N}$ heterocyclic donor in cis- $\left[\mathrm{Pt}\left(\mathrm{NH}_{3}\right)_{2}\right.$ (phenanthridine $\left.) \mathrm{Cl}\right]\left[\mathrm{OSO}_{2} \mathrm{CF}_{3}\right]$ and cis$\left[\mathrm{Pt}\left(\mathrm{NH}_{3}\right)_{2}(\right.$ pyridine $\left.) \mathrm{Cl}\right]\left[\mathrm{OSO}_{2} \mathrm{CF}_{3}\right] .{ }^{25}$ In all 2-M complexes, the phenanthridinyl $\mathrm{N}(1)-\mathrm{M}$ distances are shorter than the quinolinyl $\mathrm{N}(3)-\mathrm{M}$ distance trans to them, and also shorter than the corresponding phenanthridinyl N(3)-M bond distance in 3-M (which is trans to a phenanthridinyl donor), however the values are not distinguishable outside of the $3 \sigma$ statistical limit (Table 2). The comparable bond distances suggest similar donor strengths for the phenanthridinyl and quinolinyl arms as well, however they may also be a consequence of the rigid tridentate ligand scaffold.

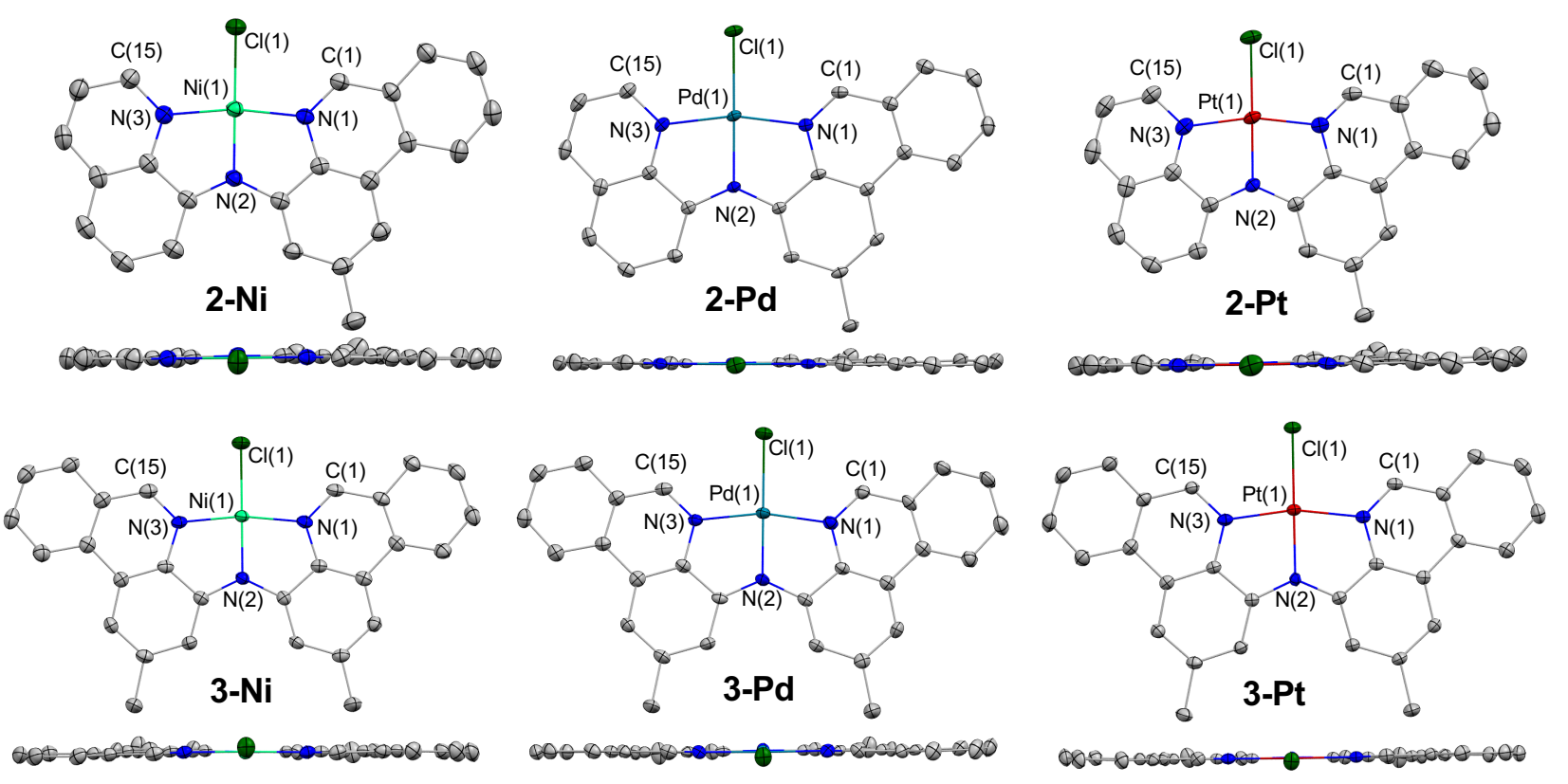

Figure 4. ORTEPs $^{21}$ with thermal ellipsoids shown at 50\% (2-Pd, 3-Ni, 3-Pd) and 30\% (2-Ni) probability levels, and hydrogens omitted for clarity. For each structure, a top view perpendicular to the metal square plane and a bottom view along the Cl-M-N(2) axis are shown. Selected bond angles $\left({ }^{\circ}\right)$ for 2-Ni: N(1)-Ni(1)-N(3) 169.31(12), Cl(1)-Ni(1)-N(2) 178.67(10), N(1)-Ni(1)-N(2) 
84.72(12), N(3)-Ni(1)-N(2) 84.60(13), N(1)-Ni(1)-Cl(1) 95.33(9), N(3)-Ni(1)-Cl(1) 95.34(10).

2-Pd: $\mathrm{N}(1)-\mathrm{Pd}(1)-\mathrm{N}(3)$ 165.94(8), Cl(1)-Pd(1)-N(2) 179.66(6), N(1)-Pd(1)-N(2) 83.05(8), N(3)-

Pd(1)-N(2) 82.89(8), N(1)-Pd(1)-Cl(1) 97.28(6), N(3)-Pd(1)-Cl(1) 96.78(6). 2-Pt: N(1)-Pt(1)N(3) 166.16(9), Cl(1)-Pt(1)-N(2) 179.20(7), N(1)-Pt(1)-N(2) 83.29(9), N(3)-Pt(1)-N(2) 82.88(9), N(1)-Pt(1)-Cl(1) 97.24(7), N(3)-Pt(1)-Cl(1) 96.60(7). 3-Ni: N(1)-Ni(1)-N(3) 169.48(9), Cl(1)$\mathrm{Ni}(1)-\mathrm{N}(2) \quad 176.71(7), \mathrm{N}(1)-\mathrm{Ni}(1)-\mathrm{N}(2) \quad 84.84(9), \mathrm{N}(3)-\mathrm{Ni}(1)-\mathrm{N}(2) \quad 84.68(9), \mathrm{N}(1)-\mathrm{Ni}(1)-\mathrm{Cl}(1)$ 95.20(6)， N(3)-Ni(1)-Cl(1) 95.31(7). 3-Pd: $\quad \mathrm{N}(1)-\mathrm{Pd}(1)-\mathrm{N}(3) \quad$ 166.04(12)， Cl(1)-Pd(1)-N(2) 177.52(9), N(1)-Pd(1)-N(2) 82.89(13), N(3)-Pd(1)-N(2) 83.17(12), N(1)-Pd(1)-Cl(1) 97.22(9), N(3)-Pd(1)-Cl(1) 96.74(9). 3-Pt: N(1)-Pt(1)-N(3) 166.12(7), Cl(1)-Pt(1)-N(2) 178.56(6), N(1)$\operatorname{Pt}(1)-\mathrm{N}(2) \quad 83.16(8), \quad \mathrm{N}(3)-\mathrm{Pt}(1)-\mathrm{N}(2) \quad 82.98(8), \quad \mathrm{N}(1)-\mathrm{Pt}(1)-\mathrm{Cl}(1) \quad 96.84(6), \quad \mathrm{N}(3)-\mathrm{Pt}(1)-\mathrm{Cl}(1)$ 97.04(6).

Table 2. Selected bond distances for 1-M (from reference ${ }^{16 c}$ ) and 2-M/3-M (this work).

\begin{tabular}{|c|c|c|c|c|c|c|}
\hline Distance $(\AA)$ & $\mathbf{M}-\mathbf{N}(\mathbf{1})^{a}$ & $\mathbf{M}-\mathbf{N}(3)^{b}$ & $\mathrm{M}-\mathrm{N}(2)$ & $\mathrm{M}-\mathrm{Cl}(1)^{c}$ & $\mathbf{N}(1)-C(1)$ & $\mathrm{N}(3)-\mathrm{C}(15)^{d}$ \\
\hline 1-Ni & $1.8973(16)$ & $1.8973(16)$ & $1.8586(14)$ & $2.1779(5)$ & $1.323(2)$ & $1.326(2)$ \\
\hline $2-\mathrm{Ni}$ & $1.899(3)$ & $1.906(3)$ & $1.858(3)$ & $2.2067(11)$ & $1.316(4)$ & $1.331(5)$ \\
\hline $3-\mathrm{Ni}$ & $1.900(2)$ & $1.900(2)$ & $1.858(2)$ & $2.2080(7)$ & $1.312(3)$ & $1.311(3)$ \\
\hline 1-Pd & $2.0114(19)$ & $2.0017(19)$ & $1.962(2)$ & $2.3298(7)$ & $1.331(3)$ & $1.329(3)$ \\
\hline 2-Pd & $1.997(2)$ & $2.001(2)$ & $1.9620(19)$ & $2.3406(6)$ & $1.301(3)$ & $1.331(3)$ \\
\hline 3-Pd & $2.001(3)$ & $2.001(3)$ & $1.959(3)$ & $2.3387(10)$ & $1.308(5)$ & $1.301(5)$ \\
\hline 1-Pt & $1.994(3)$ & $1.999(3)$ & $1.966(3)$ & $2.3175(11)$ & $1.338(5)$ & $1.318(5)$ \\
\hline 2-Pt & $1.993(2)$ & $1.999(2)$ & $1.969(2)$ & $2.3427(7)$ & $1.302(4)$ & $1.331(3)$ \\
\hline 3-Pt & $1.995(2)$ & $1.991(2)$ & $1.9779(18)$ & $2.3449(6)$ & $1.312(3)$ & $1.315(3)$ \\
\hline
\end{tabular}

${ }^{a}$ Quinolinyl-N in 1-M; phenanthridinyl-N in 2-M/3-M

${ }^{b}$ Quinolinyl-N in 1-M/2-M; phenanthridinyl-N in 3-M 
${ }^{c} \mathrm{Cl}(1)$ shows close contact to $\mathrm{CHCl}_{3}$ in lattice of $\mathbf{2 - M} / \mathbf{3}-\mathbf{M}$

${ }^{d}$ Labeled C(10) in reference ${ }^{16 c}$

\section{UV-Visible Absorption Spectroscopy}

The electronic absorption spectra of proligands L1-L3 and metal complexes 1-M, 2-M, and 3M were measured in both $\mathrm{CH}_{2} \mathrm{Cl}_{2}$ and $\mathrm{N}, \mathrm{N}$-dimethylformamide. The absorption observed for 1M/2-M/3-M obeys Beers' Law only over a limited low concentration range $\left(<5 \times 10^{-5} \mathrm{M}\right)$, suggesting ground-state aggregation may occur at higher concentrations. The UV-Vis absorption spectra of L1, L2 and $\mathbf{L 3}$ are marked by a broad peak at low energy, whose maximum shifts to shorter wavelength (L1: $400 \mathrm{~nm}$; L2: $392 \mathrm{~nm}$; L3: $382 \mathrm{~nm}$; Figure 5a) with increasing conjugation. However, this low energy peak also broadens, and the onset of absorption is observed at higher wavelengths (i.e., $\lambda_{\text {onset }} \mathbf{L 3}>\mathbf{L} \mathbf{2}>\mathbf{L 1}$ ). For comparison, the first absorption band maximum of phenanthridine itself is found at $343 \mathrm{~nm}$ (hexanes, $\pi-\pi^{*}$ ), shifting slightly to $346 \mathrm{~nm}$ in methanol, ${ }^{26}$ while the analogous peak for quinoline is at $311 \mathrm{~nm}$ (ethanol). ${ }^{27}$ Consistent with the deep red color of all nine metal complexes, spectra collected for 1-M, 2-M and 3-M contained a broad absorption with a maximum at $\sim 500 \mathrm{~nm}$ (Figures $5 \mathrm{~b}-\mathrm{d}$, Table 3 ). The significant red shift of the lowest energy peak for L1-L3 upon coordination to a metal is consistent with metal participation in the transition (i.e., M- $\pi^{*}$ metal-to-ligand charge transfer (MLCT) character) in addition to ligand-centred $\pi-\pi^{*}$ character. ${ }^{16 d,} 22$ The large extinction coefficients support the contribution of charge transfer to this transition.

In contrast to the free amines, there is no significant shift in the maximum of this broad absorption band when changing from $\mathbf{L} \mathbf{1}$ to $\mathbf{L} \mathbf{2}$ to $\mathbf{L 3}$ for any of the three series of metal complexes. This was surprising, given we intuitively expected extending ligand conjugation to have some impact on the frontier orbital energies. Modest broadening of the low energy 
absorption can be seen for $\mathbf{1 - N i / 2 - N i / 3 - N i ~ a n d ~ 1 - P d / 2 - P d / 3 - P d , ~ w i t h ~ t h e ~ f u l l ~ w i d t h ~ a t ~ h a l f ~} \max$ (FWHM) increasing on average by $7 \mathrm{~nm}$, and up to $17 \mathrm{~nm}$ when the FWHM for the broad absorption of 1-Pd is compared with 3-Pd. As with L1-L3, the onset of absorption is observed at higher wavelengths as well (i.e., $\lambda_{\text {onset }} \mathbf{3}-\mathbf{M}>\mathbf{2}-\mathbf{M}>\mathbf{1 - M} ; \mathbf{M}=\mathrm{Ni}, \mathrm{Pd}$ ). The low energy absorptions for 1-Pt/2-Pt/3-Pt are essentially unchanged by the alterations to the ligand structure. The major difference to the absorption spectrum for each of the three series of metal complexes is the appearance of up to four additional peaks at higher energy (300-430 nm), that grow in intensity when comparing complexes of $\mathbf{L 2}$ and $\mathbf{L 3}$, and therefore result from the phenanthridinyl arms.

(a)

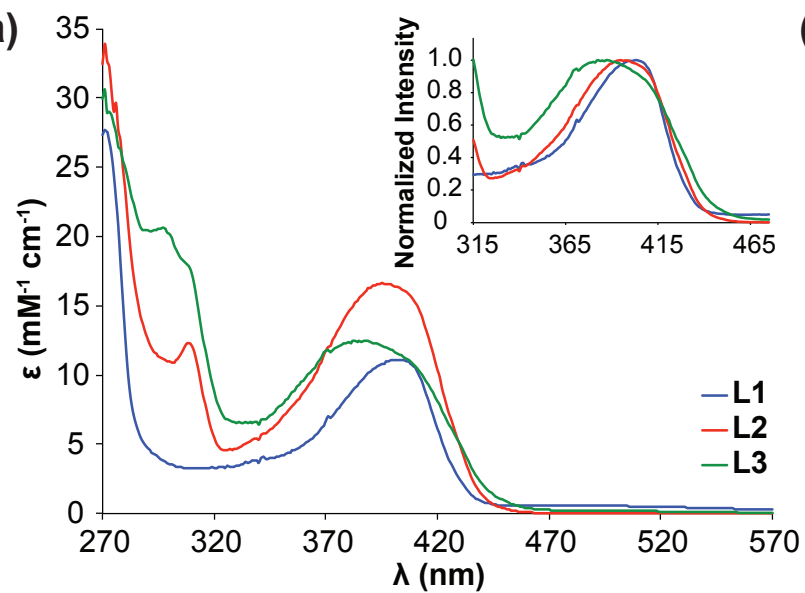

(c)

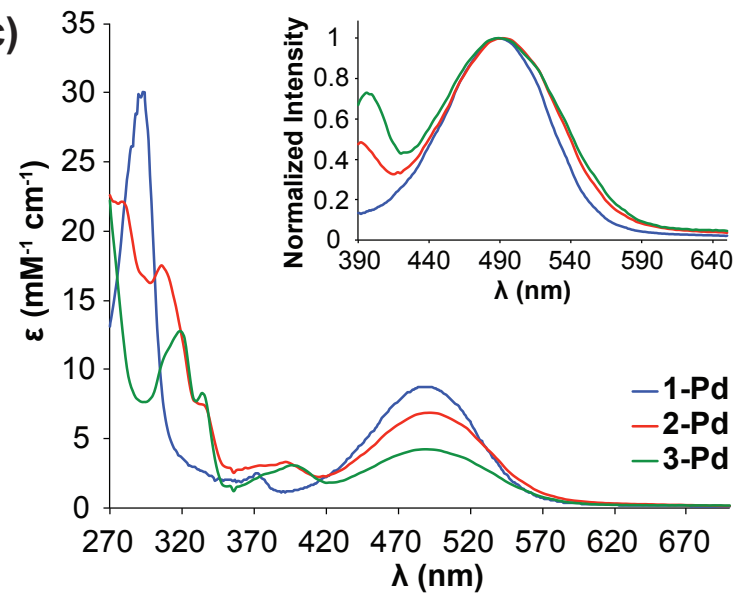

(b)

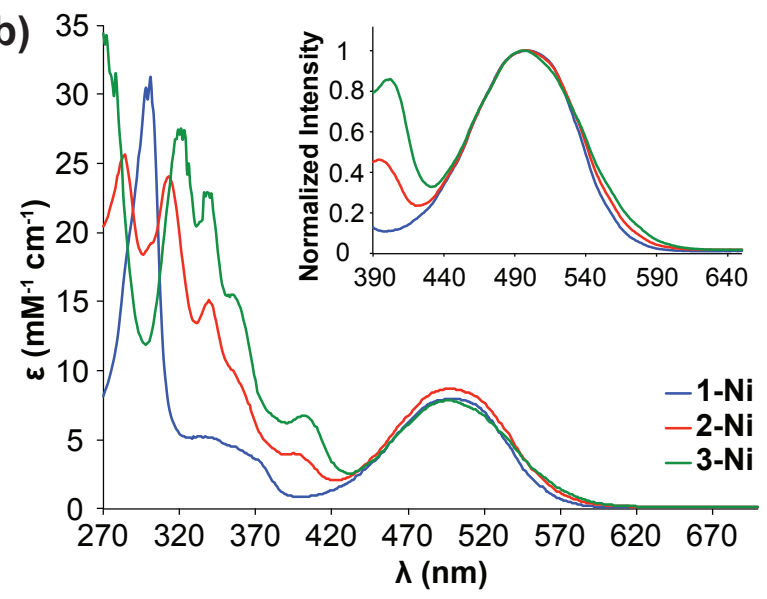

(d)

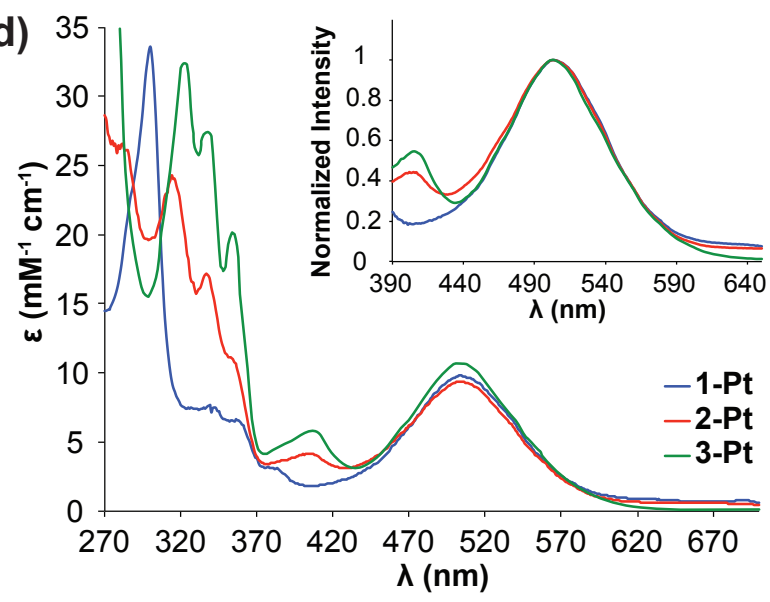


Figure 5. UV-Vis absorption spectra $\left(\mathrm{CH}_{2} \mathrm{Cl}_{2}, 22{ }^{\circ} \mathrm{C}\right)$ for (a) $\mathbf{L 1}-\mathbf{L 3}$, (b) 1-Ni/2-Ni/3-Ni, (c) 1Pd/2-Pd/3-Pd, (d) 1-Pt/2-Pt/3-Pt.

\section{Electrochemistry of 1-M, 2-M and 3-M}

The invariant position of the maximum of the lowest energy absorption band observed for each set of metal complexes led us to expect that the optical HOMO-LUMO gap is mostly unaffected by increasing conjugation from $\mathbf{1 - M}$ to $\mathbf{2}-\mathbf{M}$ to $\mathbf{3}-\mathbf{M}$, apart from a slight red shift indicated by the shift in the long wavelength edge of the absorption spectra. Electrochemistry has been used to evaluate trends in the relative energies of the frontier orbitals within series of similar compounds. $^{28}$

The electrochemical properties of 1-M, 2-M, and 3-M were examined in solution using cyclic voltammetry (CV) and differential pulse voltammetry (DPV; Figure 6, Table 3). All complexes show irreversible reduction waves at $\sim-2 \mathrm{~V}\left(\mathrm{vs} \mathrm{Fc}^{0 /+} ; \mathrm{Fc}=\right.$ ferrocene $)$ with no return wave apparent at any of the tested scan rates $\left(50-800 \mathrm{mV} \cdot \mathrm{s}^{-1}\right)$. The low solubility of the compounds results in the appearance of a pre-peak feature observed in the cathodic scans not observed at faster scan rates, attributed to adsorption of dissolved complex onto the electrode surface. ${ }^{29}$ This is particularly pronounced for the Pt complexes (the maximum solution concentration achieved with 3-Pt was $0.72 \mathrm{mM})$. Comparing these reductive events for $\mathbf{1 - M} / \mathbf{2}-\mathbf{M} / \mathbf{3}-\mathbf{M}(\mathbf{M}=\mathrm{Ni}, \mathrm{Pd})$, a slight anodic shift is observed with extended conjugation $(\mathbf{1}-\mathbf{M} \rightarrow \mathbf{2}-\mathbf{M} \rightarrow \mathbf{3}-\mathbf{M})$. This trend is in keeping with the conventional expectation that a larger $\pi$-system would stabilize the negative charge to a greater extent, however we are cautious in over-interpreting this observation due to the issues with low complex solubility. In contrast, a slight cathodic shift is observed for the Pt series, with $E_{\text {peak,cathodic }}(\mathbf{3}-\mathbf{P t})<E_{\text {peak,cathodic }}(\mathbf{2}-\mathbf{P t})<E_{\text {peak,cathodic }}(\mathbf{1}-\mathbf{P t})$. 


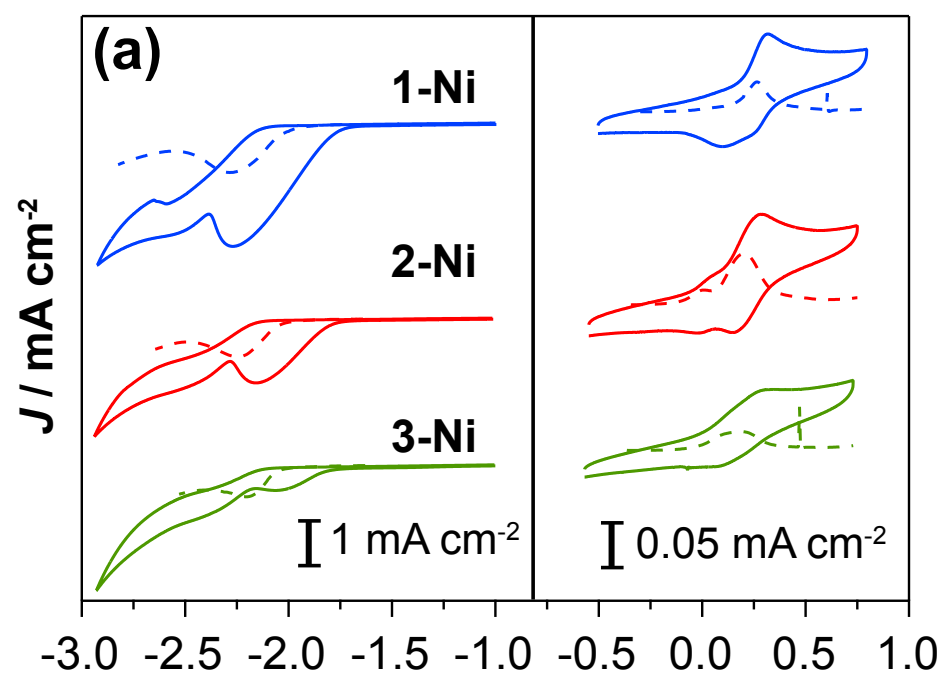

$E / V$ vs $\mathrm{Fc}^{0 /+}$
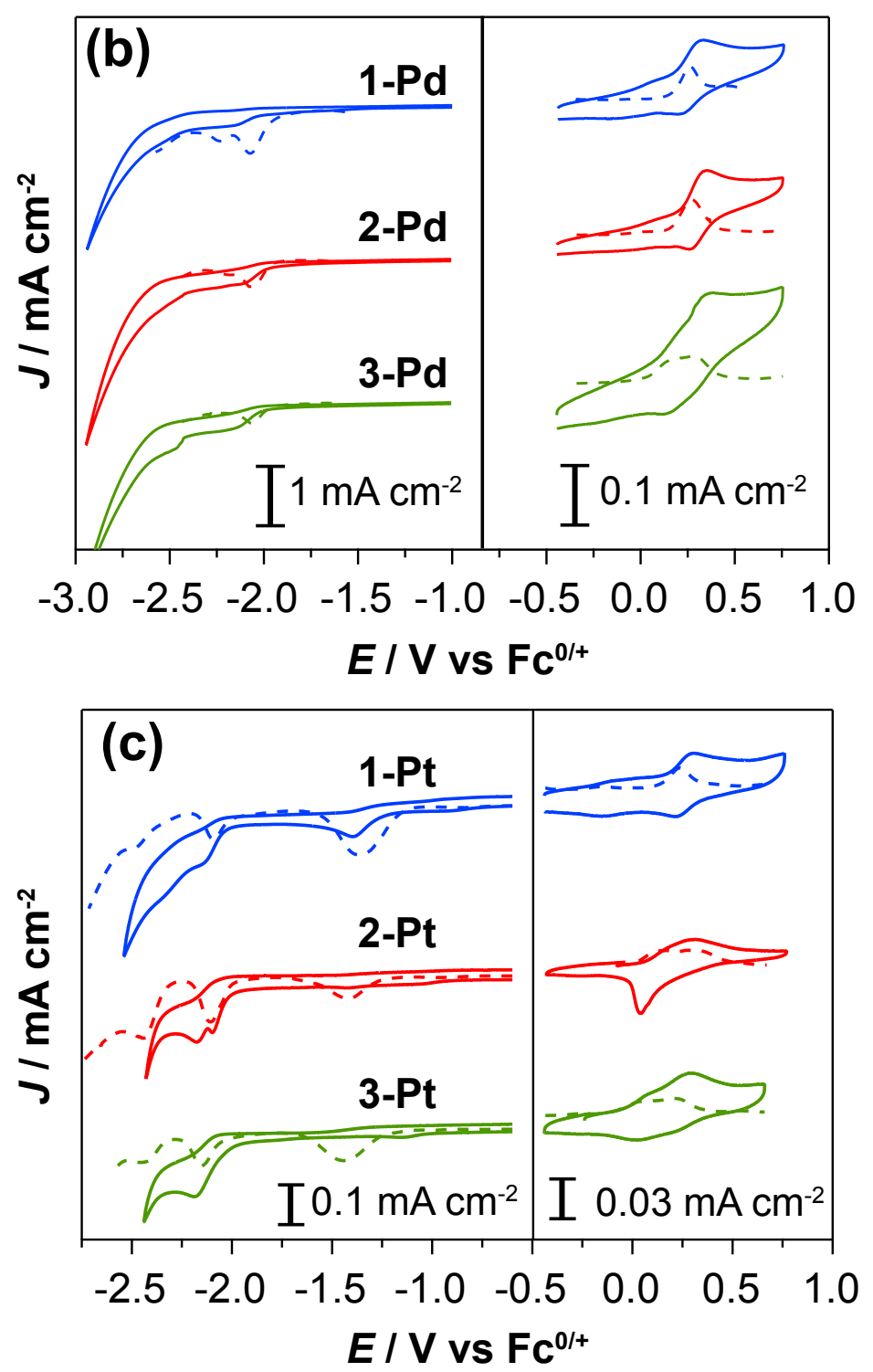
Figure 6. Cyclic voltammograms (-) and corresponding differential pulse voltammograms (---) of 1-M, 2-M, and 3-M $(1.5 \mathrm{mg} / 15 \mathrm{~mL})$ in $\mathrm{CH}_{2} \mathrm{Cl}_{2}$ with $0.1 \mathrm{M}\left[n \mathrm{Bu}_{4} \mathrm{~N}\right]\left[\mathrm{PF}_{6}\right]$ as the supporting electrolyte; (a) $\mathrm{M}=\mathrm{Ni}$, (b) $\mathrm{M}=\mathrm{Pd}$, (c) $\mathrm{M}=\mathrm{Pt}$. CV scan rates were $100 \mathrm{mV} / \mathrm{s}$. Data in the high and low potential regions were collected in separate scans.

Quasi-reversible, broad oxidation events were also observed for all nine complexes at $\sim 0.2 \mathrm{~V}$ vs $\mathrm{Fc}^{0 /+}$. The addition of a second fused ring in 3-M leads to the appearance of a second broad feature at less anodic potentials. While we cannot rule out whether this feature is due to aggregate formation, no visible deposition was observed on the electrodes following these scans; so far we have been unable to isolate a soluble chemically oxidized cationic species. In comparison, $\mathrm{Pt}$ complexes of $\pi$-extended derivatives of 1,3-bis(2pyridiylimino)pyrrole/pyrrolate/isoindolate exhibited reversible reductions and irreversible oxidations. ${ }^{\text {Id }}$ The reduction and oxidation events, respectively, observed for all nine Group 10 metal complexes of L1-L3 are within a relatively narrow potential window. This is consistent with largely ligand-based redox events influenced by coordination to a metal; ${ }^{30}$ the redox chemistry of organic $N$-heterocycle fused phenanthridines has been reported in a similar range $\left(0.38-1.5 \mathrm{~V}\right.$ vs $\left.\mathrm{Fc}^{0 /+}\right) .{ }^{31}$ Taking the difference between the first observed oxidation event and the reduction peak observed by $\operatorname{DPV}\left(\Delta \mathrm{E}_{\text {oxl-red }}\right)$, the relative HOMO-LUMO gap for the series of complexes can be estimated. The irreversibility of the peaks and presence of an absorption prefeature makes it problematic to precisely quantify the HOMO-LUMO separation using redox data, but the relative trend for all three metals is that $\Delta \mathrm{E}_{\mathrm{ox}-1 \mathrm{red}}$ decreases with increasing conjugation $(\mathbf{1 - M} \rightarrow \mathbf{2 - M} \rightarrow \mathbf{3}-\mathbf{M}) .^{32}$ 
Table 3. Electrochemical potentials and UV-Vis absorption parameters for complexes 1-3(Ni, Pd, Pt).

\begin{tabular}{|c|c|c|c|c|c|}
\hline & $E_{\text {peak, red }}{ }^{\mathrm{a} /} / \mathbf{V}$ & $E_{\text {peak, ox }}{ }^{\mathrm{a} / \mathrm{V}}$ & $\Delta \mathbf{E}_{\text {ox1-ed }}$ b/V & $\lambda^{\mathrm{c}} / \mathbf{n m}\left(\varepsilon / \mathbf{M}^{-1} \mathbf{c m}^{-1} 10^{-3}\right)$ & $\begin{array}{l}\text { FWHM } \\
\lambda_{\max } / \mathbf{n m}^{\mathrm{d}}\end{array}$ \\
\hline $\mathbf{1 - N i}$ & -2.28 & 0.26 & 2.54 & $\begin{array}{c}301(31.2), 337(5.2), 371(\mathrm{sh}) \\
499(8.0)\end{array}$ & 86 \\
\hline $2-\mathbf{N i}$ & -2.25 & 0.20 & 2.45 & $\begin{array}{c}284(25.6), 313(24.1), 339 \\
(15.1), 356(\mathrm{sh}), 395(4.0), 498 \\
(8.7)\end{array}$ & 89 \\
\hline $3-\mathbf{N i}$ & -2.20 & $0.16^{\mathrm{e}}$ & $2.36^{\mathrm{e}}$ & $\begin{array}{l}319(27.4), 336(22.9), 354 \\
(15.5), 402(6.7), 496(7.8)\end{array}$ & 91 \\
\hline 1-Pd & -2.08 & 0.26 & 2.34 & $291(29.8), 372(2.5), 489(8.8)$ & 87 \\
\hline 2-Pd & -2.06 & 0.27 & 2.33 & $\begin{array}{c}278(22.1), 306(17.5), 338 \\
(\mathrm{sh}), 392(3.3), 492(6.9)\end{array}$ & 98 \\
\hline 3-Pd & -2.05 & $0.18,0.30$ & 2.23 & $\begin{array}{c}308(\mathrm{sh}), 318(12.8), 334(8.3) \\
398(3.1), 489(4.2)\end{array}$ & 104 \\
\hline 1-Pt & $-2.09,-1.37^{\mathrm{f}}$ & 0.25 & 2.34 & $\begin{array}{l}300(33.6), 339(7.7), 356 \\
(6.6), 383(3.1), 503(9.8)\end{array}$ & 87 \\
\hline 2-Pt & $-2.10,-1.40^{\mathrm{f}}$ & $0.15,0.31$ & 2.25 & $\begin{array}{c}\text { 314(24.3), } 337(17.2), 353(\mathrm{sh}) \\
405(4.2), 503(9.4)\end{array}$ & 91 \\
\hline 3-Pt & $-2.15,-1.45^{\mathrm{f}}$ & $0.05,0.20$ & 2.20 & $\begin{array}{c}322(32.4), 336(27.4), 354 \\
(20.1), 406(5.6), 503(10.7)\end{array}$ & 88 \\
\hline
\end{tabular}

${ }^{\text {a }}$ Measured for $\mathrm{CH}_{2} \mathrm{Cl}_{2}$ solutions with $0.1 \mathrm{M}\left[n \mathrm{Bu}_{4} \mathrm{~N}\right]\left[\mathrm{PF}_{6}\right]$ as the supporting electrolyte, via DPV with potentials reported referenced to the $\mathrm{Fc}^{0 /+}$ redox couple.

${ }^{\mathrm{b}} \Delta \mathrm{E}_{\mathrm{p}}=\mathrm{E}^{\mathrm{ox}}{ }_{1 / 2}-\mathrm{E}^{\mathrm{red}}$

${ }^{c}$ Ambient temperature, $\mathrm{CH}_{2} \mathrm{Cl}_{2}$

${ }^{\mathrm{d}}$ Maximum of broad peak observed at lowest energy in spectrum in $\mathrm{CH}_{2} \mathrm{Cl}_{2}$

e Value represents middle of two unresolved peaks.

${ }^{\mathrm{f}}$ Surface-based deposition observable only at slow scan rates and/or DPV. 


\section{ELECTRONIC STRUCTURE CALCULATIONS}

We carried out density functional theory (DFT) calculations, incorporating a polarizable continuum model (DFT-PCM) to model solvent effects, and time-dependent DFT-PCM (TDDFT-PCM) calculations to probe the impact of benzannulation on the electronic structure of 1-M/2-M/3-M, and explain the experimental UV-Vis absorption spectra. As the trends for the $\mathrm{Ni}$ and $\mathrm{Pd}$ systems were found to be similar, only the Ni complexes are presented. The Pt complexes were not analyzed for this work. All structures were optimized with (SMD-M06/6$31+\mathrm{G}(\mathrm{d}, \mathrm{p}))$ and optimized geometries are in good agreement with the experimental X-ray crystallography data (see Supporting Information for details). ${ }^{33}$

The trends in calculated energies shown in Table 4 correspond well with those observed in the experimental electrochemistry. The calculated HOMO energy levels increase with extended conjugation of the ligand $(\mathbf{1}-\mathbf{M} \rightarrow \mathbf{2}-\mathbf{M} \rightarrow \mathbf{3}-\mathbf{M})$, consistent with the observed cathodic shift in oxidation potential. The observed trend in the onset of reduction potentials is not reproduced; however, as noted above, the irreversibility of the cathodic electrochemical events and presence of absorption pre-features complicate precise analysis of the peak positions.

Using the optimized structures, vertical excitation energies were determined using TDDFT. The lowest energy vertical transitions for solution (SMD) calculations are in good qualitative agreement with the experimental absorption trends (Table 3). Consistent with the observed experimental spectra, the increase in conjugation in the ligands has little effect on the position of the low energy absorption of the metal complexes. However, benzannulation does impact the nature of the absorption, as can be seen through analysis of atomic contributions to the computed molecular orbitals. 
Our calculations on the complex with the smallest $\pi$-system (1-Ni) predict that the $\mathrm{HOMO} \rightarrow$ LUMO transition defines the lowest energy excitation at $494 \mathrm{~nm}(98 \%$ calculated contribution). The HOMO of this complex consists largely of contributions from the $\pi$ system of the $\mathrm{C}_{6}$-benzo rings and amido lone pair, with small contributions from the $\mathrm{d}$ - and p-orbitals of the nickel and chloride respectively, and the $\mathrm{C}-\mathrm{N} \pi$ bond of the quinolinyl rings (Figure 7). The LUMO of this system has a small contribution from the Ni but is otherwise largely delocalized across the $\pi$ system of the ligand.

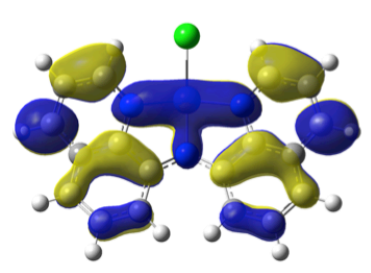

1-Ni (LUMO+1)

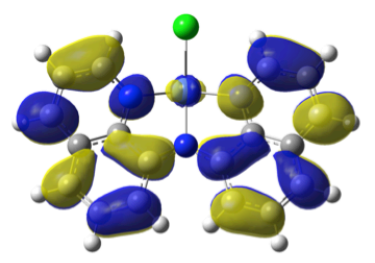

1-Ni (LUMO)

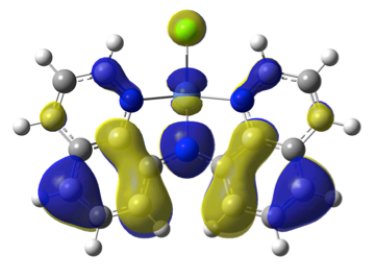

1-Ni (HOMO)

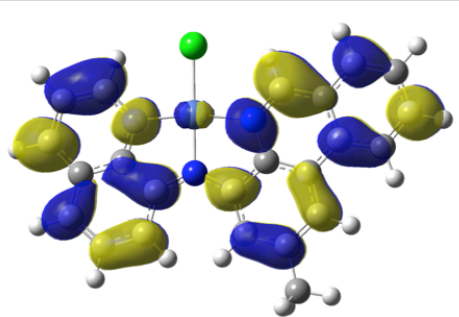

2-Ni (LUMO+1)
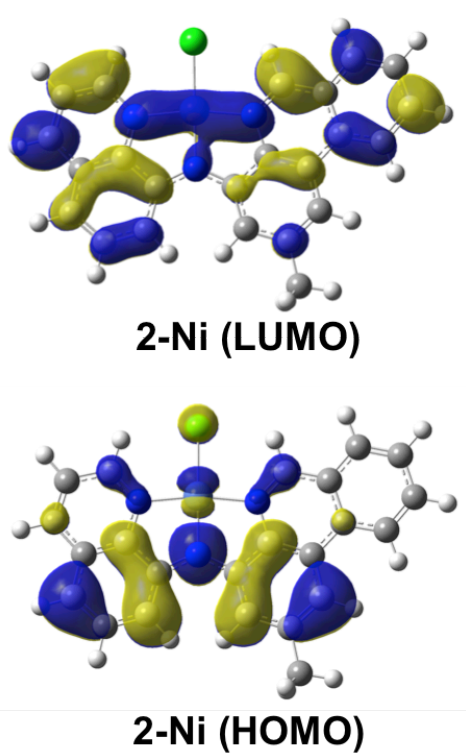

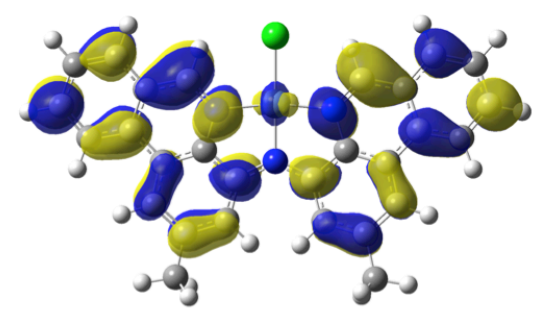

3-Ni (LUMO+1)

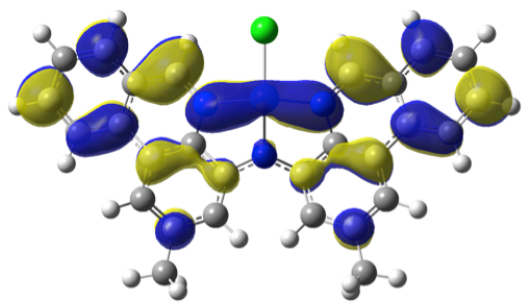

3-Ni (LUMO)

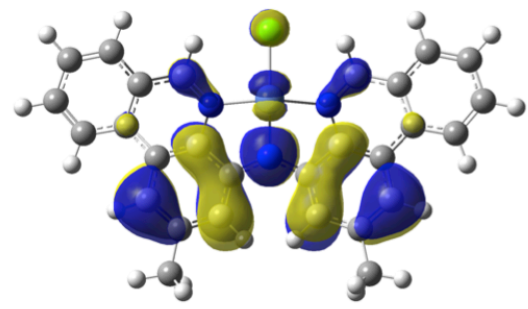

3-Ni (HOMO)

Figure 7. Orbital diagrams of the HOMO, LUMO and LUMO+1 for 1-Ni, 2-Ni, and 3-Ni. 
The extended $\pi$ system of $\mathbf{2}-\mathbf{N i}$ produces two low energy excitations at $491 \mathrm{~nm}$ and $484 \mathrm{~nm}$ with nearly equal oscillator strengths (Table 4). The excitation at $491 \mathrm{~nm}$ is dominated by the HOMO $\rightarrow$ LUMO transition $(58 \%$ calculated contribution $)$ but contains significant $\mathrm{HOMO} \rightarrow \mathrm{LUMO}+1$ character $(41 \%$ calculated contribution). The excitation at $484 \mathrm{~nm}$ is dominated by the HOMO $\rightarrow$ LUMO +1 transition $(57 \%)$ but contains significant HOMO $\rightarrow$ LUMO character $(41 \%)$. The HOMO of this system is similar to that of 1-Ni in that it consists largely of contributions from the $\pi$ system of the benzo moieties, the central amido lone pair and, to a smaller extent, the $\mathrm{C}=\mathrm{N} \pi$-bond. The LUMO of $\mathbf{2}-\mathbf{N i}$ consists of contributions from both ligand arms and Ni. Qualitatively, the structure of the LUMO+1 in the calculated structure of 2-Ni more closely resembles the orbital configuration of the LUMO of 1-Ni and is delocalized across the $\pi$ system of the ligand (Figure 7). Further expansion of the $\pi$ system of the ligand in 3-Ni produces an excitation at $490 \mathrm{~nm}$ that is defined by the HOMO $\rightarrow$ LUMO+1 transition (97\%). The orbital contributions of the HOMO, LUMO and LUMO+1 of the 3-Ni complex closely resemble those of the 2-Ni complex, with the LUMO/LUMO+1 character inverted compared to 1-Ni (Figure 7). The main impact of benzannulation in the series $\mathbf{1 - N i \rightarrow 2 - N i \rightarrow 3 - N i ~ t h e r e f o r e ~ a p p e a r s ~ t o ~ b e ~ t o ~}$ cause the energy of the LUMO of 1-Ni to rise, while at the same time lowering the energy of the LUMO+1 (which becomes the LUMO of $\mathbf{2}-\mathbf{N i}$ and $\mathbf{3}-\mathbf{N i}$ ). The orbital contributions to the HOMO, in comparison, remain largely unchanged from $\mathbf{1}-\mathbf{N i} \rightarrow \mathbf{2}-\mathbf{N i} \rightarrow \mathbf{3}-\mathbf{N i}$, while the energy of this orbital is calculated to rise slightly, in keeping with conventional expectations of extended conjugation and consistent with the trends in the experimental anodic electrochemistry. Interestingly, in both pseudo- $C_{2 v}$ symmetric complexes (1-Ni and 3-Ni), only one low energy transition has significant calculated oscillator strength and the atomic contributions to the orbitals 
involved in this transition are very similar. In the $C_{\mathrm{s}}$ symmetric $\mathbf{2 - N i}$, both the HOMO $\rightarrow$ LUMO and $\mathrm{HOMO} \rightarrow \mathrm{LUMO}+1$ transitions contribute to the low energy absorptions.

This is qualitatively consistent with Gordon and Thompson's model ${ }^{1 \mathrm{~d}}$ for understanding shifts in frontier orbital energies following benzannulation: there is minimal HOMO density at the site of benzannulation in 1-Ni by a conceptual cis-1,3-butadiene fragment. No orbital mixing or significant change to the HOMO energy/character would therefore be expected. In contrast, there is a bisecting nodal plane in the LUMO of $\mathbf{1 - N i}$ at the site of benzannulation. There is therefore a symmetry match with the HOMO of a cis-1,3-butadiene fragment ( $\mathrm{a}_{2}, C_{2 v}$ point group), which can therefore act as an effective electron-donating group to the LUMO of 1-Ni, leading to its destabilization.

Table 4. TDDFT Vertical Excitation Energies and HOMO, LUMO, and LUMO+1 energies for complexes $\mathbf{1 - N i / 2 - N i / 3 - N i . ~}$

\begin{tabular}{|l|c|c|c|c|l|c|c|c|}
\hline & $\begin{array}{c}\text { HOMO } \\
(\mathbf{e V})\end{array}$ & $\begin{array}{c}\text { LUMO } \\
(\mathbf{e V})\end{array}$ & $\begin{array}{c}\text { LUMO+1 } \\
(\mathbf{e V})\end{array}$ & $\begin{array}{c}\lambda_{\text {calc }} \\
(\mathbf{n m})\end{array}$ & \multicolumn{1}{|c|}{ Assignment } & $\begin{array}{c}\text { Oscillator } \\
\text { Strength }\end{array}$ & Coefficient & $\begin{array}{c}\text { \% Con- } \\
\text { tribution }\end{array}$ \\
\hline $\mathbf{1 - N i}$ & -5.35 & -1.90 & -1.85 & 494.34 & HOMO $\rightarrow$ LUMO & 0.3698 & 0.70142 & 98.4 \\
& & & & 483.13 & HOMO $\rightarrow$ LUMO+1 & 0.0078 & 0.70319 & 98.9 \\
\hline $\mathbf{2 - N i}$ & -5.32 & -1.88 & -1.84 & 490.66 & HOMO $\rightarrow$ LUMO & 0.2131 & 0.53712 & 57.7 \\
& & & & & HOMO $\rightarrow$ LUMO+1 & & 0.45206 & 40.9 \\
& & & & 483.83 & HOMO $\rightarrow$ LUMO & 0.1722 & -0.45215 & 40.9 \\
& & & & & HOMO $\rightarrow$ LUMO+1 & & 0.53581 & 57.4 \\
\hline $\mathbf{3 - N i}$ & -5.28 & -1.90 & -1.79 & 496.51 & HOMO $\rightarrow$ LUMO & 0.0221 & 0.70183 & 98.5 \\
& & & & 485.04 & HOMO $\rightarrow$ LUMO+1 & 0.3536 & 0.69707 & 97.2 \\
\hline
\end{tabular}

In a relevant literature example, similarly extending ligand conjugation for a series of annulated meso-tetraphenylmetalloporphyrins was found not to significantly impact the energy of the HOMO and LUMO with respect to the parent porphyrin, but did lead to significant destabilization of the HOMO- $1 .{ }^{34}$ In this case, destabilization of the HOMO-1 led to this orbital 
rising above the parent HOMO in energy (and become the new HOMO in the benzannulated complexes), thus leading to a red shift in the absorption and emission spectra. A similar effect occurs in the series $\mathbf{1 - N i} \rightarrow \mathbf{2}-\mathbf{N i} \rightarrow \mathbf{3 - N i}$, where the orbitals comprising the LUMO and LUMO+1 in the parent complex (1-Ni) formally change positions upon benzannulation (2-Ni/3-Ni). In our series, however, the slight rise in the energy of the HOMO upon benzannulation is matched by a similar rise in the energy of the LUMO+1. The shift in the character of the lowest energy transition from $\mathrm{HOMO} \rightarrow$ LUMO $(\mathbf{1 - N i})$ to $\mathrm{HOMO} \rightarrow$ LUMO/HOMO $\rightarrow$ LUMO+1 to strictly $\mathrm{HOMO} \rightarrow \mathrm{LUMO}+1$ (3-Ni) then results in similar energies for these transitions calculated by theory and observed experimentally.

\section{CONCLUSION}

A synthetic methodology has been established allowing the preparation of a series of tridentate proligands templated on bis(8-quinolinyl)amine (L1), bearing one (L2) or two phenanthridinyl (L3) units. Compounds L2-L3 bind as tridentate, mer-bound pincer-like amido ligands to divalent group 10 metal ions $(\mathrm{Ni}, \mathrm{Pd}$ and $\mathrm{Pt})$. In contrast to the differences observed in the low energy absorption transitions of $\mathbf{L 1 - L 3}$, the maxima observed for the lowest energy absorptions of 1-M to 2-M to 3-M (M = Ni, Pd, Pt) do not shift appreciably, though the onset of absorption edges to higher wavelengths, consistent with the trend of slight red shift in the HOMO-LUMO gap estimated from electrochemistry. DFT calculations reveal that, more so than simply impacting the frontier orbital energies, benzannulation strongly affects the atomic contributions to the LUMO and LUMO+1, with the orbital character of these MOs in 2-M and 3-M switched compared with 1-M. In addition, while the lowest energy absorption in the bis(quinolinyl) 1-M is dominated by the HOMO $\rightarrow$ LUMO excitation, the analogous absorption in the 
bis(phenanthridinyl) 3-M is dominated by the HOMO $\rightarrow$ LUMO+1 excitation; the mixed quinolinyl/phenanthridinyl 2-M has both $\mathrm{HOMO} \rightarrow \mathrm{LUMO}$ and $\mathrm{HOMO} \rightarrow \mathrm{LUMO}+1$ character. This suggests that complexes of ligands L1-L3 with heavier metals such as 1-Pt, 2-Pt and 3-Pt may present interesting trends in their emission spectra, where a straightforward correlation with the extent of $\pi$-conjugation may not exist and the orbital structure of the frontier orbitals may influence other parameters such as radiative rate constants and zero-field splittings. Investigations to this extent are currently underway in our labs.

\section{EXPERIMENTAL SECTION}

Unless otherwise specified, all air sensitive manipulations were carried out either in a $\mathrm{N}_{2}$ filled glove box or using standard Schlenk techniques under Ar. 2-Formylphenylboronic acid (AK Scientific), $N$-iodosuccinimide (AK Scientific), $N$-bromosuccinimide (Alpha Aesar), $\mathrm{Pd}\left(\mathrm{PPh}_{3}\right)_{4}$ (Sigma Aldrich), Pd(OAc) $)_{2}$ (Sigma Aldrich), (1,1'-diphenylphosphino)ferrocene (dppf, Sigma Aldrich), $\mathrm{Na}_{2} \mathrm{CO}_{3}$ (Alpha Aesar), trifluoroacetic acid (Sigma Aldrich), sodium tert-pentoxide (NaOtPen, Sigma Aldrich), sodium tert-butoxide ( $\mathrm{NaO} t \mathrm{Bu}$, Sigma Aldrich), zinc (Alpha Aesar), hydrazine hydrate (Sigma Aldrich), formic acid (Alpha Aesar), and $\mathrm{NiCl}_{2} \cdot 6 \mathrm{H}_{2} \mathrm{O}$ (Alpha Aesar) were purchased and used without any further purification. 2-bromo-4-methylaniline, ${ }^{35} \operatorname{Pd}(1,5-$ cyclooctadiene $) \mathrm{Cl}_{2},{ }^{36} \mathrm{Pt}(1,5$-cyclooctadiene $) \mathrm{Cl}_{2}, \mathbf{L 1}, \mathbf{1 - N i C l}, \mathbf{1 - P d C l}$ and $\mathbf{1 - P t C l}{ }^{16 c}$ were synthesized according to published procedures. Organic solvents were dried and distilled using appropriate drying agents prior to use. Distilled water was degassed prior to use. 1- and 2D NMR spectra were recorded on Bruker Avance $300 \mathrm{MHz}$ or Bruker Avance-III $500 \mathrm{MHz}$ spectrometers. ${ }^{1} \mathrm{H}$ and ${ }^{13} \mathrm{C}\left\{{ }^{1} \mathrm{H}\right\}$ NMR spectra were referenced to residual solvent peaks. ${ }^{37}$ Elemental analyses were performed by Microanalytical Service Ltd., Delta, BC (Canada). 
For electrochemical analysis, 1-2 mg of each compound was dissolved in $15 \mathrm{~mL}$ of $\mathrm{CH}_{2} \mathrm{Cl}_{2}$ containing $0.1 \mathrm{M}\left(n \mathrm{Bu}_{4} \mathrm{~N}\right) \mathrm{PF}_{6}$, and purged with $\mathrm{Ar}$ for 20 minutes before analysis. All electrochemical experiments were conducted under inert (Ar) atmosphere using a CHI 760c bipotentiostat, a freshly polished (0.03 $\mu \mathrm{m}$ alumina paste) $3 \mathrm{~mm}$ diameter glassy carbon working electrode (BASi), a $\mathrm{Ag} / \mathrm{Ag}^{+}$quasi-non-aqueous reference electrode separated by a Vycor tip, and a Pt wire counter electrode. Cyclic voltammetric (CV) experiments were conducted using scan rates of 50-800 mV/s. Differential Pulse Voltammetry (DPV) experiments were conducted using a $5 \mathrm{mV}$ increment, $50 \mathrm{mV}$ amplitude, $0.1 \mathrm{~s}$ pulse width, $0.0167 \mathrm{~s}$ sample width, and $0.5 \mathrm{~s}$ pulse period. Upon completion of all CV and DPV analyses, ferrocene $(\mathrm{Fc})$ was added to the solution as an internal standard, with all potentials reported versus the $\mathrm{Fc}^{0 /+}$ redox couple..$^{38}$

Preparation of 2-bromo-6-iodo-p-toluidine: Trifluoroacetic acid (30 mol \%, $1.23 \mathrm{~mL}$ ) was added to a stirred acetonitrile solution $(300 \mathrm{~mL})$ of 2-bromo-4-methylaniline $(10.1 \mathrm{~g}, 53.7 \mathrm{mmol})$ at $0{ }^{\circ} \mathrm{C}$, followed by addition of $N$-iodosuccinimide $(12.7 \mathrm{~g}, 56.4 \mathrm{mmol})$ in small portions over $1.5 \mathrm{~h}$. The mixture was stirred for $0.5 \mathrm{~h}$ at this temperature, after which the ice bath was removed and stirring continued for $2 \mathrm{~h}$. The solvent was then removed in vacuo, the residue taken up in $\mathrm{CH}_{2} \mathrm{Cl}_{2}$, and washed with brine (3 x $100 \mathrm{~mL}$ ). The organic layer was dried over $\mathrm{Na}_{2} \mathrm{SO}_{4}$, and volatiles removed to leave a gray solid, which was used without further purification. Isolated yield $=16.0 \mathrm{~g}(95 \%)$. The ${ }^{1} \mathrm{H}$ NMR spectrum was consistent with that previously reported ${ }^{39}$

Preparation of 2-iodo-6-nitro-p-toluidine: An identical procedure to the synthesis of 2bromo-6-iodo- $p$-toluidine was employed, using 2-nitro- $p$-toluidine $(5.01 \mathrm{~g}, 32.9 \mathrm{mmol})$ and $N$ - 
iodosuccinimide $(12.7 \mathrm{~g}, 34.5 \mathrm{mmol})$. Isolated yield of orange solid $=7.60 \mathrm{~g}(96 \%)$. The ${ }^{1} \mathrm{H}$ NMR spectrum was consistent with previously reported values..$^{40}$

Preparation of 4-bromo-2-methylphenanthridine (4-Br): A $500 \mathrm{~mL}$ Teflon-stoppered flask was charged with $\mathrm{Pd}\left(\mathrm{PPh}_{3}\right)_{4}(0.87 \mathrm{~g}, 0.75 \mathrm{mmol})$, and $50 \mathrm{~mL}$ of 1,2-dimethoxyethane (DME). After stirring briefly to mix, 2-bromo-6-iodo-p-toluidine $(7.80 \mathrm{~g}, 25.0 \mathrm{mmol}), 2$ formylphenylboronic acid $(4.16 \mathrm{~g}, 27.8 \mathrm{mmol})$ and an additional $70 \mathrm{~mL}$ of DME were added, followed by $\mathrm{Na}_{2} \mathrm{CO}_{3}(8.0 \mathrm{~g}, 76 \mathrm{mmol})$ dissolved in $100 \mathrm{~mL}$ of degassed water. The flask was then sealed and the mixture stirred vigorously for $6 \mathrm{~h}$ in an oil bath $\left(130^{\circ} \mathrm{C}\right)$. The flask was then allowed to cool, charged with $80 \mathrm{~mL}$ of $2 \mathrm{M} \mathrm{HCl}$, and refluxed for additional $2 \mathrm{~h}$. The reaction mixture was cooled, neutralized with $\mathrm{NaOH}$, and pumped to dryness. The residue was then taken up in $\mathrm{CH}_{2} \mathrm{Cl}_{2}(100 \mathrm{~mL})$ and washed with brine $(3 \times 100 \mathrm{~mL})$. The organic layer was separated, dried over $\mathrm{Na}_{2} \mathrm{SO}_{4}$ and volatiles removed to leave yellow-brown solid. Column chromatography on basic alumina gave a pale yellow solid $\left(\mathrm{R}_{\mathrm{f}}=0.41 ; 1: 5 \mathrm{EtOAc} /\right.$ hexane $)$. Isolated yield $=6.3 \mathrm{~g}$ (91\%). ${ }^{1} \mathrm{H}$ NMR $\left(\mathrm{CDCl}_{3}, 500 \mathrm{MHz}, 22{ }^{\circ} \mathrm{C}\right): \delta 9.29\left(\mathrm{~s}, 1 \mathrm{H}, \mathrm{C}_{6}-\mathrm{H}\right), 8.52\left(\mathrm{~d}, 1 \mathrm{H}, J_{\mathrm{HH}}=8.3 \mathrm{~Hz}, \mathrm{C}_{10^{-}}\right.$ $\mathrm{H}), 8.26\left(\mathrm{~s}, 1 \mathrm{H}, \mathrm{C}_{3}-\mathrm{H}\right), 8.03\left(\mathrm{~d}, 1 \mathrm{H}, J_{\mathrm{HH}}=7.9 \mathrm{~Hz}, \mathrm{C}_{7}-\mathrm{H}\right), 7.90-7.77$ (overlapped m, $2 \mathrm{H}, \mathrm{C}_{1}-\mathrm{H}, \mathrm{C}_{9}-$ $\mathrm{H}), 7.70\left(\operatorname{app~t}, 1 \mathrm{H}, J_{\mathrm{HH}}=7.5 \mathrm{~Hz}, \mathrm{C}_{8}-\mathrm{H}\right), 2.57 \mathrm{ppm}\left(\mathrm{s}, 3 \mathrm{H}, \mathrm{CH}_{3}\right) .{ }^{13} \mathrm{C}\left\{{ }^{1} \mathrm{H}\right\} \mathrm{NMR}\left(\mathrm{CDCl}_{3}, 300\right.$ $\left.\mathrm{MHz}, 22{ }^{\circ} \mathrm{C}\right): \delta 153.5\left(\mathrm{C}_{6}\right), 144.3\left(\mathrm{C}_{\mathrm{Ar}}\right), 142.8\left(\mathrm{C}_{\mathrm{Ar}}\right), 140.0\left(\mathrm{C}_{\mathrm{Ar}}\right), 137.8\left(\mathrm{C}_{\mathrm{Ar}}\right), 134.1\left(\mathrm{C}_{1}\right), 132.1$ $\left(\mathrm{C}_{\mathrm{Ar}}\right), 131.3\left(\mathrm{C}_{9}\right), 129.0\left(\mathrm{C}_{7}\right), 128.1\left(\mathrm{C}_{8}\right), 126.6\left(\mathrm{C}_{\mathrm{Ar}}\right), 125.6\left(\mathrm{C}_{\mathrm{Ar}}\right), 125.4\left(\mathrm{C}_{\mathrm{Ar}}\right), 122.1\left(\mathrm{C}_{10}\right), 121.7$ $\left(\mathrm{C}_{3}\right), 21.7 \mathrm{ppm}\left(\mathrm{CH}_{3}\right)$.

Preparation of 2-methyl-4-nitrophenanthridine $\left(4-\mathrm{NO}_{2}\right)$ : An identical procedure to the synthesis of 4-bromo-2-methylphenanthridine was employed, using $\mathrm{Pd}\left(\mathrm{PPh}_{3}\right)_{4}(0.42 \mathrm{~g}, 0.36$ 
mmol), 2-iodo-6-nitro-p-toluidine $(5.02 \mathrm{~g}, 18.0 \mathrm{mmol})$, and 2-formylphenylboronic acid (3.01 g, $20.0 \mathrm{mmol})$. Following column chromatography $\left(\mathrm{R}_{\mathrm{f}}=0.25 ; 1: 5 \mathrm{EtOAc} / \mathrm{hexane}\right)$, isolated yield of yellow-brown solid = $4.0 \mathrm{~g}(93 \%) .{ }^{1} \mathrm{H} \mathrm{NMR}\left(\mathrm{CDCl}_{3}, 300 \mathrm{MHz}, 22{ }^{\circ} \mathrm{C}\right): \delta 9.34\left(\mathrm{~s}, 1 \mathrm{H}, \mathrm{C}_{6}-\mathrm{H}\right)$, $8.61\left(\mathrm{~d}, 1 \mathrm{H}, J_{\mathrm{HH}}=8.3 \mathrm{~Hz}, \mathrm{C}_{10}-\mathrm{H}\right), 8.54\left(\mathrm{~s}, 1 \mathrm{H}, \mathrm{C}_{3}-\mathrm{H}\right), 8.11\left(\mathrm{~d}, 1 \mathrm{H}, J_{\mathrm{HH}}=7.9 \mathrm{~Hz}, \mathrm{C}_{7}-\mathrm{H}\right), 7.99-7.89$ $\left(\mathrm{m}, 1 \mathrm{H}, \mathrm{C}_{9}-\mathrm{H}\right), 7.88-7.71$ (overlapped m, $\left.2 \mathrm{H} ; \mathrm{C}_{1}-\mathrm{H}, \mathrm{C}_{8}-\mathrm{H}\right), 2.69 \mathrm{ppm}\left(\mathrm{s}, 3 \mathrm{H}, \mathrm{CH}_{3}\right) .{ }^{13} \mathrm{C}\left\{{ }^{1} \mathrm{H}\right\} \mathrm{NMR}$ $\left(\mathrm{CDCl}_{3}, 300 \mathrm{MHz}, 2{ }^{\circ} \mathrm{C}\right): \delta 155.1\left(\mathrm{C}_{6}\right), 149.3\left(\mathrm{C}_{\mathrm{Ar}}\right), 136.8\left(\mathrm{C}_{\mathrm{Ar}}\right), 134.3\left(\mathrm{C}_{\mathrm{Ar}}\right), 132.0\left(\mathrm{C}_{8}\right), 131.3$ $\left(\mathrm{C}_{\mathrm{Ar}}\right), 129.3\left(\mathrm{C}_{7}\right), 128.9\left(\mathrm{C}_{9}\right), 126.7\left(\mathrm{C}_{\mathrm{Ar}}\right), 125.6\left(\mathrm{C}_{\mathrm{Ar}}\right), 125.5\left(\mathrm{C}_{3}\right), 123.8\left(\mathrm{C}_{1}\right), 122.2\left(\mathrm{C}_{10}\right), 21.9$ $\operatorname{ppm}\left(\mathrm{CH}_{3}\right)$.

Preparation of 4-amino-2-methylphenanthridine (4-NH $\mathrm{NH}_{2}$ : To a stirred solution of 4-NO $(5.02 \mathrm{~g}, 21.0 \mathrm{mmol})$ in methanol $(100 \mathrm{~mL}), \mathrm{Zn}$ dust $(2.75 \mathrm{~g}, 42.0 \mathrm{mmol})$, and hydrazinium monoformate solution $(54 \mathrm{~mL}$; prepared by slowly neutralizing equal molar amounts of hydrazine hydrate $(50 \mathrm{~mL})$ with $85 \%$ formic acid $(4 \mathrm{~mL})$ in an ice-water bath) were added, and stirred vigorously at $60{ }^{\circ} \mathrm{C}$. The resulting green suspension was cooled and filtered using celite. The filtrate was pumped dry, the residue dissolved in $\mathrm{CH}_{2} \mathrm{Cl}_{2}(100 \mathrm{~mL})$, and washed with brine (3 x $60 \mathrm{~mL}$ ). The organic layer was dried over $\mathrm{Na}_{2} \mathrm{SO}_{4}$, filtered, and the volatiles removed to leave a green-brown solid, which was purified using column chromatography (basic alumina, $\mathrm{R}_{\mathrm{f}}$ $=0.25 ; 1: 5 \mathrm{EtOAc} /$ hexane $).$ Isolated yield $=3.74 \mathrm{~g}(86 \%) .{ }^{1} \mathrm{H} \mathrm{NMR}\left(\mathrm{CDCl}_{3}, 300 \mathrm{MHz}, 22{ }^{\circ} \mathrm{C}\right)$ : $\delta 9.07\left(\mathrm{~s}, 1 \mathrm{H}, \mathrm{C}_{6}-\mathrm{H}\right), 8.52\left(\mathrm{~d}, 1 \mathrm{H}, J_{\mathrm{HH}}=8.3 \mathrm{~Hz}, \mathrm{C}_{10}-\mathrm{H}\right), 7.97\left(\mathrm{~d}, 1 \mathrm{H}, J_{\mathrm{HH}}=7.9 \mathrm{~Hz}, \mathrm{C}_{7}-\mathrm{H}\right), 7.86-$ $7.74\left(\mathrm{~m}, 1 \mathrm{H}, \mathrm{C}_{9}-\mathrm{H}\right), 7.69-7.61$ (overlapped m, 2H; $\left.\mathrm{C}_{1}-\mathrm{H}, \mathrm{C}_{8}-\mathrm{H}\right), 6.85$ (s, 1H, $\left.\mathrm{C}_{3}-\mathrm{H}\right), 4.96$ (br s, 2H, N-H), $2.51 \mathrm{ppm}\left(\mathrm{s}, 3 \mathrm{H}, \mathrm{CH}_{3}\right) \cdot{ }^{13} \mathrm{C}\left\{{ }^{1} \mathrm{H}\right\} \mathrm{NMR}\left(\mathrm{CDCl}_{3}, 300 \mathrm{MHz}, 22{ }^{\circ} \mathrm{C}\right): \delta 149.4\left(\mathrm{C}_{6}\right), 144.5$ $\left(\mathrm{C}_{\mathrm{Ar}}\right), 137.8\left(\mathrm{C}_{\mathrm{Ar}}\right), 132.6\left(\mathrm{C}_{\mathrm{Ar}}\right), 132.0\left(\mathrm{C}_{\mathrm{Ar}}\right), 130.4\left(\mathrm{C}_{\mathrm{Ar}}\right), 128.6\left(\mathrm{C}_{\mathrm{Ar}}\right), 127.1\left(\mathrm{C}_{\mathrm{Ar}}\right), 126.8\left(\mathrm{C}_{\mathrm{Ar}}\right)$, 124.6 $\left(\mathrm{C}_{\mathrm{Ar}}\right), 122.4\left(\mathrm{C}_{\mathrm{Ar}}\right), 113.1\left(\mathrm{C}_{\mathrm{Ar}}\right), 110.9\left(\mathrm{C}_{3}\right), 22.4 \mathrm{ppm}\left(\mathrm{CH}_{3}\right)$. 


\section{Synthesis of Me-Phen $N N(H) N^{\text {Quin }}$ (4-methyl-phenanthridinyl)(8-quinolinyl)amine (L2): A}

$500 \mathrm{~mL}$ Teflon-stoppered flask was charged with $\mathrm{Pd}(\mathrm{OAc})_{2}(0.25 \mathrm{~g}, 1.10 \mathrm{mmol})$, 1,2diphenylphosphinoferrocene (dppf; $0.96 \mathrm{~g}, 1.76 \mathrm{mmol})$, and toluene (30 mL). After stirring briefly, 4-Br (6.01 g, $22.0 \mathrm{mmol}), 8$-aminoquinoline (3.33 g, $23 \mathrm{mmol})$ and an additional $120 \mathrm{~mL}$ of toluene were added, followed by sodium tert-pentoxide (NaOtPen; $3.60 \mathrm{~g}, 33.0 \mathrm{mmol})$ and the mixture stirred vigorously for $72 \mathrm{~h}$ in an oil bath $\left(150^{\circ} \mathrm{C}\right)$. After cooling the flask and removing the volatiles, the residue was taken up in $\mathrm{CH}_{2} \mathrm{Cl}_{2}(120 \mathrm{~mL})$, and the resulting suspension filtered over celite and dried to leave a red solid, which was purified using column chromatography (basic alumina; 1:5 EtOAc/hexane; $\left.\mathrm{R}_{\mathrm{f}}=0.5\right)$. Isolated yield $=6.8 \mathrm{~g}(93 \%) .{ }^{1} \mathrm{H} \mathrm{NMR}\left(\mathrm{CDCl}_{3}\right.$, $\left.500 \mathrm{MHz}, 22{ }^{\circ} \mathrm{C}\right): \delta 10.69$ (br s, $\left.1 \mathrm{H}, \mathrm{N}-\mathrm{H}\right), 9.27\left(\mathrm{~s}, 1 \mathrm{H}, \mathrm{C}_{6}-\mathrm{H}\right), 8.99$ (dd, $1 \mathrm{H}, J_{\mathrm{HH}}=4.1,1.7 \mathrm{~Hz}$; $\left.{ }^{\text {Quin }} \mathrm{C}_{\mathrm{Ar}}-\mathrm{H}\right), 8.57\left(\mathrm{~d}, 1 \mathrm{H}, J_{\mathrm{HH}}=8.3 \mathrm{~Hz} ;{ }^{P h e n} \mathrm{C}_{\mathrm{Ar}}-\mathrm{H}\right), 8.14\left(\mathrm{dd}, 1 \mathrm{H}, J_{\mathrm{HH}}=8.2,1.6 \mathrm{~Hz} ;{ }^{\text {Quin }} \mathrm{C}_{\mathrm{Ar}}-\mathrm{H}\right)$, $8.04\left(\mathrm{~d}, 1 \mathrm{H}, J_{\mathrm{HH}}=7.7 \mathrm{~Hz} ;{ }^{P h e n} \mathrm{C}_{\mathrm{Ar}}-\mathrm{H}\right), 7.94\left(\mathrm{~d}, 1 \mathrm{H}, J_{\mathrm{HH}}=7.6 \mathrm{~Hz} ;{ }^{\text {Quin }} \mathrm{C}_{\mathrm{Ar}}-\mathrm{H}\right), 7.86\left(\mathrm{~s}, 1 \mathrm{H},{ }^{P h e n} \mathrm{C}_{\mathrm{Ar}}-\right.$ $\mathrm{H}), 7.85\left(\mathrm{~s}, 1 \mathrm{H},{ }^{P h e n} \mathrm{C}_{\mathrm{Ar}}-\mathrm{H}\right), 7.83-7.77\left(\mathrm{~m}, 1 \mathrm{H},{ }^{\text {Phen }} \mathrm{C}_{\mathrm{Ar}}-\mathrm{H}\right), 7.67$ (app t, $1 \mathrm{H}, J_{\mathrm{HH}}=7.7 \mathrm{~Hz}$; ${ }^{P h e n} \mathrm{C}_{\mathrm{Ar}}{ }^{-}$ H), $7.54\left(\operatorname{app~t,~} 1 \mathrm{H}, J_{\mathrm{HH}}=7.9 \mathrm{~Hz},{ }^{\text {Quin }} \mathrm{C}_{\mathrm{Ar}}-\mathrm{H}\right), 7.45\left(\mathrm{dd}, 1 \mathrm{H}, J_{\mathrm{HH}}=8.2,4.2 \mathrm{~Hz}\right.$; $\left.{ }^{\text {Quin }} \mathrm{C}_{\mathrm{Ar}}-\mathrm{H}\right), 7.32(\mathrm{~d}$, $\left.1 \mathrm{H}, J_{\mathrm{HH}}=8.1 \mathrm{~Hz},{ }^{\text {Quin }} \mathrm{C}_{\mathrm{Ar}}-\mathrm{H}\right), 2.65 \mathrm{ppm}\left(\mathrm{s}, 3 \mathrm{H}, \mathrm{CH}_{3}\right) .{ }^{13} \mathrm{C}\left\{{ }^{1} \mathrm{H}\right\} \mathrm{NMR}\left(\mathrm{CDCl}_{3}, 500 \mathrm{MHz}, 22{ }^{\circ} \mathrm{C}\right)$ : $\delta 150.1\left({ }^{\text {Phen }} \mathrm{C}_{\mathrm{Ar}} \mathrm{H}\right), 148.1\left({ }^{\text {Quin }} \mathrm{C}_{\mathrm{Ar}} \mathrm{H}\right), 140.2\left(\mathrm{C}_{\mathrm{Ar}}\right), 139.4\left(\mathrm{C}_{\mathrm{Ar}}\right), 139.2\left(\mathrm{C}_{\mathrm{Ar}}\right), 137.5\left(\mathrm{C}_{\mathrm{Ar}}\right), 136.2$ $\left({ }^{\text {Quin }} \mathrm{C}_{\mathrm{Ar}} \mathrm{H}\right), 133.8\left(\mathrm{C}_{\mathrm{Ar}}\right), 132.6\left(\mathrm{C}_{\mathrm{Ar}}\right), 130.6\left({ }^{\text {Phen }} \mathrm{C}_{\mathrm{Ar}} \mathrm{H}\right), 129.1\left(\mathrm{C}_{\mathrm{Ar}}\right), 128.7\left({ }^{\mathrm{Phen}} \mathrm{C}_{\mathrm{Ar}} \mathrm{H}\right), 127.3$ $\left({ }^{\text {Quin }} \mathrm{C}_{\mathrm{Ar}} \mathrm{H}\right), 127.2\left({ }^{\text {Phen }} \mathrm{C}_{\mathrm{Ar}} \mathrm{H}\right), 126.4\left(\mathrm{C}_{\mathrm{Ar}}\right), 124.8\left(\mathrm{C}_{\mathrm{Ar}}\right), 122.4\left({ }^{\text {Phen }} \mathrm{C}_{\mathrm{Ar}} \mathrm{H}\right), 121.7\left({ }^{\text {Quin }} \mathrm{C}_{\mathrm{Ar}} \mathrm{H}\right), 117.7$ $\left({ }^{\text {Quin }} \mathrm{C}_{\mathrm{Ar}} \mathrm{H}\right), 112.8\left({ }^{\text {Phen }} \mathrm{C}_{\mathrm{Ar}} \mathrm{H}\right), 112.6\left({ }^{\text {Phen }} \mathrm{C}_{\mathrm{Ar}} \mathrm{H}\right), 109.8\left({ }^{\text {Quin }} \mathrm{C}_{\mathrm{Ar}} \mathrm{H}\right), 22.9$ ppm $\left(\mathrm{CH}_{3}\right) . \mathrm{UV}-\mathrm{Vis}$ (DMF): $\lambda(\varepsilon) 267$ (45 400), 308 (14 700), $392 \mathrm{~nm}\left(17650 \mathrm{M}^{-1} \mathrm{~cm}^{-1}\right)$. 


\section{Synthesis of Me-Phen NN(H)N $\mathbf{N}^{\text {Phen-Me }}$ bis(4-methylphenanthridinyl)amine (L3): A $500 \mathrm{~mL}$}

Teflon-stoppered flask was charged with $\mathrm{Pd}(\mathrm{OAc})_{2}(0.25 \mathrm{~g}, 1.10 \mathrm{mmol})$, dppf $(0.96 \mathrm{~g}, 1.76$ $\mathrm{mmol})$, and $30 \mathrm{~mL}$ of toluene and stirred briefly. Next, 4-Br $(6.02 \mathrm{~g}, 22.1 \mathrm{mmol}), \mathbf{4 - \mathbf { N H } _ { 2 }}(5.01 \mathrm{~g}$, $24.0 \mathrm{mmol})$ and an additional $120 \mathrm{~mL}$ of toluene were added, followed by $\mathrm{NaO} t \mathrm{Pen}(3.60 \mathrm{~g}, 32.6$ mmol). The flask was then sealed and the mixture stirred vigorously for $72 \mathrm{~h}$ in an oil bath (150 $\left.{ }^{\circ} \mathrm{C}\right)$ then dried in vacuo. Isolation and work up was as for $\mathbf{L 2}\left(\mathrm{R}_{\mathrm{f}}=0.5 ; 1: 5 \mathrm{EtOAc} / \mathrm{hexane}\right)$. Isolated yield $=7.9 \mathrm{~g}(90 \%) .{ }^{1} \mathrm{H} \mathrm{NMR}\left(\mathrm{CDCl}_{3}, 300 \mathrm{MHz}, 22{ }^{\circ} \mathrm{C}\right): \delta 10.63(\mathrm{br} \mathrm{s}, 1 \mathrm{H}, \mathrm{N}-\mathrm{H}), 9.29$ $\left(\mathrm{s}, 2 \mathrm{H}, \mathrm{C}_{6}-\mathrm{H}\right), 8.61\left(\mathrm{~d}, 2 \mathrm{H}, J_{\mathrm{HH}}=8.3 \mathrm{~Hz}, \mathrm{C}_{10}-\mathrm{H}\right), 8.08\left(\operatorname{app~d}, 2 \mathrm{H}, J_{\mathrm{HH}}=8.0 \mathrm{~Hz}, \mathrm{C}_{7}-\mathrm{H}\right), 7.90-7.80$ (overlapped m, 6H; $\mathrm{C}_{1}-\mathrm{H}, \mathrm{C}_{3}-\mathrm{H}, \mathrm{C}_{9}-\mathrm{H}$ ), 7.73-7.67 (app t, 2H, $\left.J_{\mathrm{HH}}=7.5 \mathrm{~Hz}, \mathrm{C}_{8}-\mathrm{H}\right), 2.67$ ppm (s, $\left.6 \mathrm{H}, \mathrm{CH}_{3}\right) .{ }^{13} \mathrm{C}\left\{{ }^{1} \mathrm{H}\right\}$ NMR $\left(\mathrm{CDCl}_{3}, 300 \mathrm{MHz}, 22{ }^{\circ} \mathrm{C}\right): \delta 150.1\left({ }^{\text {Phen }} \mathrm{C}_{\mathrm{Ar}} \mathrm{H}\right), 139.7\left({ }^{\text {Phen }} \mathrm{C}_{\mathrm{Ar}}\right), 137.6$ $\left({ }^{\text {Phen }} \mathrm{C}_{\mathrm{Ar}}\right), 133.9\left({ }^{\text {Phen }} \mathrm{C}_{\mathrm{Ar}}\right), 132.7\left({ }^{\text {Phen }} \mathrm{C}_{\mathrm{Ar}}\right), 130.7\left({ }^{\text {Phen }} \mathrm{C}_{\mathrm{Ar}} \mathrm{H}\right), 128.8\left({ }^{\text {Phen }} \mathrm{C}_{\mathrm{Ar}} \mathrm{H}\right), 127.3\left({ }^{\text {Phen }} \mathrm{C}_{\mathrm{Ar}} \mathrm{H}\right), 127.0$ $\left({ }^{\text {Phen }} \mathrm{C}_{\mathrm{Ar}}\right), 124.9\left({ }^{\text {Phen }} \mathrm{C}_{\mathrm{Ar}}\right), 122.5\left({ }^{\text {Phen }} \mathrm{C}_{\mathrm{Ar}} \mathrm{H}\right), 112.7\left({ }^{\text {Phen }} \mathrm{C}_{\mathrm{Ar}} \mathrm{H}\right), 112.5\left({ }^{\text {Phen }} \mathrm{C}_{\mathrm{Ar}} \mathrm{H}\right), 23.0 \mathrm{ppm}\left(\mathrm{CH}_{3}\right) . \mathrm{UV}-$ Vis (DMF): $\lambda$ (ع) 266 (44 800), 297 (24 500), 307 (shoulder), $382 \mathrm{~nm}\left(17050 \mathrm{M}^{-1} \mathrm{~cm}^{-1}\right)$.

Synthesis of ( $\left.{ }^{\text {Me-Phen }} \mathbf{N N N}^{\text {Quin }}\right) \mathbf{N i C l}(\mathbf{2 - N i}): \quad \mathrm{NiCl}^{\circ} 6 \mathrm{H}_{2} \mathrm{O}(0.14 \mathrm{~g}, 0.6 \mathrm{mmol})$ and $\mathrm{NaO} t \mathrm{Bu}(60$ $\mathrm{mg}, 0.63 \mathrm{mmol})$ were added as solids to a solution of $\mathbf{L 2}(0.2 \mathrm{~g}, 0.6 \mathrm{mmol})$ in $\mathrm{CH}_{2} \mathrm{Cl}_{2}(10 \mathrm{~mL})$ and the mixture stirred vigorously at $50{ }^{\circ} \mathrm{C}$ for $12 \mathrm{~h}$. The resulting red suspension was allowed to cool and the volatiles removed in vacuo. The residue was then washed with diethylether ( 3 x 10 $\mathrm{mL})$ and ethanol (3 x $10 \mathrm{~mL})$. While the solubility of $\mathbf{2}-\mathbf{N i}$ is poor in general, it was observed to be highest in $\mathrm{CHCl}_{3}$ compared with other common organic solvents. Isolated yield $=0.209 \mathrm{~g}(81$ \%). ${ }^{1} \mathrm{H}$ NMR $\left(\mathrm{CDCl}_{3}, 300 \mathrm{MHz}, 22{ }^{\circ} \mathrm{C}\right): \delta 9.05\left(\mathrm{~s}, 1 \mathrm{H}, \mathrm{C}_{\mathrm{Ar}}-\mathrm{H}\right), 8.71\left(\mathrm{~d}, 1 \mathrm{H}, J_{\mathrm{HH}}=4.8 \mathrm{~Hz}, \mathrm{C}_{\mathrm{Ar}}-\mathrm{H}\right)$, $8.43\left(\mathrm{~d}, 1 \mathrm{H}, J_{\mathrm{HH}}=8.3 \mathrm{~Hz}, \mathrm{C}_{\mathrm{Ar}}-\mathrm{H}\right), 8.13\left(\mathrm{~d}, 1 \mathrm{H}, J_{\mathrm{HH}}=8.2 \mathrm{~Hz}, \mathrm{C}_{\mathrm{Ar}}-\mathrm{H}\right), 7.97\left(\mathrm{~d}, J_{\mathrm{HH}}=1 \mathrm{H}, 7.9 \mathrm{~Hz}\right.$, $\left.\mathrm{C}_{\mathrm{Ar}}-\mathrm{H}\right), 7.85\left(\mathrm{t}, 1 \mathrm{H}, J_{\mathrm{HH}}=7.6 \mathrm{~Hz}, \mathrm{C}_{\mathrm{Ar}}-\mathrm{H}\right), 7.64\left(\mathrm{t}, 1 \mathrm{H}, J_{\mathrm{HH}}=7.5 \mathrm{~Hz}, \mathrm{C}_{\mathrm{Ar}}-\mathrm{H}\right), 7.55\left(\mathrm{~d}, 1 \mathrm{H}, J_{\mathrm{HH}}=7.9\right.$ 
$\left.\mathrm{Hz}, \mathrm{C}_{\mathrm{Ar}}-\mathrm{H}\right), 7.50-7.32\left(\right.$ overlapped $\left.\mathrm{m}, 3 \mathrm{H}, \mathrm{C}_{\mathrm{Ar}}-\mathrm{H}\right), 7.29\left(\mathrm{t}, 1 \mathrm{H}, J_{\mathrm{HH}}=5.4 \mathrm{~Hz}, \mathrm{C}_{\mathrm{Ar}}-\mathrm{H}\right), 6.93(\mathrm{~d}, 1 \mathrm{H}$, $\left.J_{\mathrm{HH}}=8.0 \mathrm{~Hz}\right), 2.58 \mathrm{ppm}\left(\mathrm{s}, 3 \mathrm{H}, \mathrm{CH}_{3}\right) \cdot{ }^{13} \mathrm{C}\left\{{ }^{1} \mathrm{H}\right\} \mathrm{NMR}\left(\mathrm{CDCl}_{3}, 500 \mathrm{MHz}, 22{ }^{\circ} \mathrm{C}\right): 154.1\left(\mathrm{C}_{\mathrm{Ar}} \mathrm{H}\right)$, $150.5\left(\mathrm{C}_{\mathrm{Ar}} \mathrm{H}\right), 148.4\left(\mathrm{C}_{\mathrm{Ar}}\right), 148.3\left(\mathrm{C}_{\mathrm{Ar}}\right), 147.7\left(\mathrm{C}_{\mathrm{Ar}}\right), 140.8\left(\mathrm{C}_{\mathrm{Ar}}\right), 139.9\left(\mathrm{C}_{\mathrm{Ar}} \mathrm{H}\right), 138.6\left(\mathrm{C}_{\mathrm{Ar}} \mathrm{H}\right)$, $133.0\left(\mathrm{C}_{\mathrm{Ar}}\right), 132.6\left(\mathrm{C}_{\mathrm{Ar}} \mathrm{H}\right), 130.0\left(\mathrm{C}_{\mathrm{Ar}} \mathrm{H}\right), 129.8\left(\mathrm{C}_{\mathrm{Ar}}\right), 129.5\left(\mathrm{C}_{\mathrm{Ar}} \mathrm{H}\right), 127.8\left(\mathrm{C}_{\mathrm{Ar}} \mathrm{H}\right), 126.3\left(\mathrm{C}_{\mathrm{Ar}}\right)$, $125.5\left(\mathrm{C}_{\mathrm{Ar}}\right), 122.4\left(\mathrm{C}_{\mathrm{Ar}} \mathrm{H}\right), 121.1\left(\mathrm{C}_{\mathrm{Ar}} \mathrm{H}\right), 22.8 \mathrm{ppm}\left(\mathrm{CH}_{3}\right)$. UV-Vis (DMF): $\lambda(\varepsilon) 282$ (25 750), 311 (21 800), 337 (13 200), $360(\mathrm{sh}), 400(\mathrm{sh}), 485 \mathrm{~nm}\left(8400 \mathrm{M}^{-1} \mathrm{~cm}^{-1}\right)$. Anal. Calcd for $\mathrm{C}_{23} \mathrm{H}_{16} \mathrm{~N}_{3} \mathrm{NiCl}$ : C, 64.46; H, 3.76. Found: C, 64.30; H, 3.99.

Synthesis of (Me-Phen NNN $\left.{ }^{\text {Quin }}\right)$ PdCl (2-Pd): To a stirred solution of $\mathbf{L 2}(0.22 \mathrm{~g}, 0.66 \mathrm{mmol})$ in $10 \mathrm{~mL}$ of THF, $\mathrm{Pd}(\mathrm{COD}) \mathrm{Cl}_{2}(0.17 \mathrm{~g}, 0.60 \mathrm{mmol})$, and $\mathrm{NaO} t \mathrm{Bu}(0.060 \mathrm{~g}, 0.63 \mathrm{mmol})$ were added, and the mixture stirred vigorously at $70{ }^{\circ} \mathrm{C}$ for $12 \mathrm{~h}$. The resulting red suspension was allowed to cool, and the volatiles removed in vacuo. The residue was then washed with diethylether $(3 \times 10 \mathrm{~mL})$ and ethanol $(3 \times 10 \mathrm{~mL})$. Solubility is similar to 2-Ni. Isolated yield $=$ $0.228 \mathrm{~g}(83 \%) .{ }^{1} \mathrm{H} \mathrm{NMR}\left(\mathrm{CDCl}_{3}, 500 \mathrm{MHz}, 22{ }^{\circ} \mathrm{C}\right): \delta 9.27\left(\mathrm{~s}, 1 \mathrm{H}, \mathrm{C}_{\mathrm{Ar}}-\mathrm{H}\right), 8.96$ (br s, $1 \mathrm{H}, \mathrm{C}_{\mathrm{Ar}^{-}}$ $\mathrm{H}), 8.43\left(\mathrm{~d}, 1 \mathrm{H}, J_{\mathrm{HH}}=8.6 \mathrm{~Hz}, \mathrm{C}_{\mathrm{Ar}}-\mathrm{H}\right), 8.17\left(\mathrm{~d}, 1 \mathrm{H}, J_{\mathrm{HH}}=8.0 \mathrm{~Hz}, \mathrm{C}_{\mathrm{Ar}}-\mathrm{H}\right), 8.00\left(\mathrm{~d}, 1 \mathrm{H}, J_{\mathrm{HH}}=7.9\right.$ $\left.\mathrm{Hz}, \mathrm{C}_{\mathrm{Ar}}-\mathrm{H}\right), 7.86\left(\operatorname{app} \mathrm{t}, 1 \mathrm{H}, J_{\mathrm{HH}}=7.3 \mathrm{~Hz}, \mathrm{C}_{\mathrm{Ar}}-\mathrm{H}\right), 7.67\left(\operatorname{app~t}, 1 \mathrm{H}, J_{\mathrm{HH}}=7.0 \mathrm{~Hz}, \mathrm{C}_{\mathrm{Ar}}-\mathrm{H}\right), 7.54(\mathrm{~s}$, $1 \mathrm{H}, \mathrm{C}_{\mathrm{Ar}}-\mathrm{H}$ ), 7.48-7.43 (overlapped m, 2H, $\left.\mathrm{C}_{\mathrm{Ar}}-\mathrm{H}\right), 7.40-7.31\left(\mathrm{~m}, 1 \mathrm{H}, \mathrm{C}_{\mathrm{Ar}}-\mathrm{H}\right), 7.0$ (br s, $1 \mathrm{H}, \mathrm{C}_{\mathrm{Ar}^{-}}$ H), $2.60 \mathrm{ppm}\left(\mathrm{s}, 3 \mathrm{H}, \mathrm{CH}_{3}\right) \cdot{ }^{13} \mathrm{C}\left\{{ }^{1} \mathrm{H}\right\} \mathrm{NMR}\left(\mathrm{CDCl}_{3}, 500 \mathrm{MHz}, 22{ }^{\circ} \mathrm{C}\right): \delta 151.8\left(\mathrm{C}_{\mathrm{Ar}} \mathrm{H}\right), 149.9$ $\left(\mathrm{C}_{\mathrm{Ar}}\right), 149.8\left(\mathrm{C}_{\mathrm{Ar}}\right), 148.9\left(\mathrm{C}_{\mathrm{Ar}} \mathrm{H}\right), 148.3\left(\mathrm{C}_{\mathrm{Ar}}\right), 141.4\left(\mathrm{C}_{\mathrm{Ar}}\right), 140.1\left(\mathrm{C}_{\mathrm{Ar}} \mathrm{H}\right), 138.7\left(\mathrm{C}_{\mathrm{Ar}} \mathrm{H}\right), 132.8$ $\left(\mathrm{C}_{\mathrm{Ar}}\right), 132.7\left(\mathrm{C}_{\mathrm{Ar}} \mathrm{H}\right), 131.3\left(\mathrm{C}_{\mathrm{Ar}}\right), 129.9\left(\mathrm{C}_{\mathrm{Ar}} \mathrm{H}\right), 129.6\left(\mathrm{C}_{\mathrm{Ar}} \mathrm{H}\right), 128.1\left(\mathrm{C}_{\mathrm{Ar}} \mathrm{H}\right), 126.9\left(\mathrm{C}_{\mathrm{Ar}}\right), 126.2$ $\left(\mathrm{C}_{\mathrm{Ar}} \mathrm{H}\right), 122.6\left(\mathrm{C}_{\mathrm{Ar}} \mathrm{H}\right), 121.2\left(\mathrm{C}_{\mathrm{Ar}} \mathrm{H}\right), 114.8\left(\mathrm{C}_{\mathrm{Ar}} \mathrm{H}\right), 114.2\left(\mathrm{C}_{\mathrm{Ar}}\right), 112.5\left(\mathrm{C}_{\mathrm{Ar}}\right), 110.7\left(\mathrm{C}_{\mathrm{Ar}}\right), 22.8 \mathrm{ppm}$ $\left(\mathrm{CH}_{3}\right)$. UV-Vis (DMF): $\lambda$ (ع) 266 (30 000), 277 (28 850), 307 (22 050), 336 (sh), 392 (4 250), 
$489 \mathrm{~nm}\left(9950 \mathrm{M}^{-1} \mathrm{~cm}^{-1}\right)$. Anal. Calcd for $\mathrm{C}_{23} \mathrm{H}_{16} \mathrm{~N}_{3} \mathrm{PdCl}$ : C, 58.00; H, 3.39. Found: C, 57.54; H, 3.37.

Synthesis of ( ${ }^{\text {Me-Phen NNNQuin }}$ PtCl (2-Pt): To a stirred solution of compound L2 (0.20 g, 0.60 $\mathrm{mmol})$ in $10 \mathrm{~mL}$ of THF, $\mathrm{Pt}(\mathrm{COD}) \mathrm{Cl}_{2}(0.22 \mathrm{~g}, 0.60 \mathrm{mmol})$, and $\mathrm{NaOt} \mathrm{Bu}(0.06 \mathrm{~g}, 0.63 \mathrm{mmol})$ were added, and the mixture stirred vigorously at $70{ }^{\circ} \mathrm{C}$ for $12 \mathrm{~h}$. The resulting red suspension was allowed to cool, and the volatiles removed in vacuo. The residue was then was washed with diethylether (3 x $10 \mathrm{~mL})$ and acetonitrile $(3 \times 10 \mathrm{~mL})$. Solubility is similar to 2-Ni and 2-Pd. Isolated yield $=0.239 \mathrm{~g}(71 \%) .{ }^{1} \mathrm{H} \mathrm{NMR}\left(\mathrm{CDCl}_{3}, 500 \mathrm{MHz}, 22{ }^{\circ} \mathrm{C}\right): \delta 9.49\left(\mathrm{~s}, 1 \mathrm{H}, \mathrm{C}_{\mathrm{Ar}}-\mathrm{H}\right), 9.17$ $\left(\mathrm{d}, 1 \mathrm{H}, J_{\mathrm{HH}}=4.7 \mathrm{~Hz}, \mathrm{C}_{\mathrm{Ar}}-\mathrm{H}\right), 8.40\left(\mathrm{~d}, 1 \mathrm{H}, J_{\mathrm{HH}}=8.2 \mathrm{~Hz}, \mathrm{C}_{\mathrm{Ar}}-\mathrm{H}\right), 8.22\left(\mathrm{~d}, 1 \mathrm{H}, J_{\mathrm{HH}}=8.1 \mathrm{~Hz}, \mathrm{C}_{\mathrm{Ar}}-\mathrm{H}\right)$, $8.02\left(\mathrm{~d}, 1 \mathrm{H}, J_{\mathrm{HH}}=7.8 \mathrm{~Hz}, \mathrm{C}_{\mathrm{Ar}}-\mathrm{H}\right), 7.86\left(\operatorname{app~t}, 1 \mathrm{H}, J_{\mathrm{HH}}=7.5 \mathrm{~Hz}, \mathrm{C}_{\mathrm{Ar}}-\mathrm{H}\right), 7.67-7.65$ (overlapped $\left.\mathrm{m}, 2 \mathrm{H}, \mathrm{C}_{\mathrm{Ar}}-\mathrm{H}\right), 7.53\left(\mathrm{~s}, 1 \mathrm{H}, \mathrm{C}_{\mathrm{Ar}}-\mathrm{H}\right), 7.47-7.40$ (overlapped $\left.\mathrm{m}, 2 \mathrm{H}, \mathrm{C}_{\mathrm{Ar}}-\mathrm{H}\right), 7.36\left(\mathrm{dd}, 1 \mathrm{H}, J_{\mathrm{HH}}=7.9\right.$, $\left.4.9 \mathrm{~Hz} ; \mathrm{C}_{\mathrm{Ar}}-\mathrm{H}\right), 6.97\left(\mathrm{~d}, 1 \mathrm{H}, J_{\mathrm{HH}}=7.7 \mathrm{C}_{\mathrm{Ar}}-\mathrm{H}\right), 2.60 \mathrm{ppm}\left(\mathrm{s}, 3 \mathrm{H}, \mathrm{CH}_{3}\right) .{ }^{13} \mathrm{C}\left\{{ }^{1} \mathrm{H}\right\} \mathrm{NMR}\left(\mathrm{CDCl}_{3}, 500\right.$ $\left.\mathrm{MHz}, 22{ }^{\circ} \mathrm{C}\right): \delta 151.1\left(\mathrm{C}_{\mathrm{Ar}} \mathrm{H}\right), 149.3\left(\mathrm{C}_{\mathrm{Ar}}\right), 149.2\left(\mathrm{C}_{\mathrm{Ar}}\right), 148.7\left(\mathrm{C}_{\mathrm{Ar}}\right), 148.3\left(\mathrm{C}_{\mathrm{Ar}} \mathrm{H}\right), 142.2\left(\mathrm{C}_{\mathrm{Ar}}\right)$, $140.0\left(\mathrm{C}_{\mathrm{Ar}} \mathrm{H}\right), 138.8\left(\mathrm{C}_{\mathrm{Ar}} \mathrm{H}\right), 132.9\left(\mathrm{C}_{\mathrm{Ar}} \mathrm{H}\right), 132.7\left(\mathrm{C}_{\mathrm{Ar}} \mathrm{H}\right), 131.5\left(\mathrm{C}_{\mathrm{Ar}}\right), 129.9\left(\mathrm{C}_{\mathrm{Ar}} \mathrm{H}\right), 129.4\left(\mathrm{C}_{\mathrm{Ar}} \mathrm{H}\right)$, $128.2\left(\mathrm{C}_{\mathrm{Ar}} \mathrm{H}\right), 127.0\left(\mathrm{C}_{\mathrm{Ar}}\right), 126.2\left(\mathrm{C}_{\mathrm{Ar}}\right), 122.6\left(\mathrm{C}_{\mathrm{Ar}} \mathrm{H}\right), 121.2\left(\mathrm{C}_{\mathrm{Ar}} \mathrm{H}\right), 115.4\left(\mathrm{C}_{\mathrm{Ar}} \mathrm{H}\right), 114.7\left(\mathrm{C}_{\mathrm{Ar}}\right)$, 113.5 $\left(\mathrm{C}_{\mathrm{Ar}}\right), 111.1\left(\mathrm{C}_{\mathrm{Ar}} \mathrm{H}\right), 22.8\left(\mathrm{CH}_{3}\right)$ ppm. Anal. Calcd for $\mathrm{C}_{23} \mathrm{H}_{16} \mathrm{~N}_{3} \mathrm{PtCl}: \mathrm{C}, 48.90 ; \mathrm{H}, 2.85$. Found: C: 48.64; H: 2.87.

Synthesis of ( $\left.{ }^{\text {Me-Phen NNN }}{ }^{\text {Phen-Me }}\right)$ NiCl (3-Ni): To a stirred solution of L3 (0.20 g, $\left.0.50 \mathrm{mmol}\right)$ in $\mathrm{CH}_{2} \mathrm{Cl}_{2}(10 \mathrm{~mL}), \mathrm{NiCl}_{2} \cdot 6 \mathrm{H}_{2} \mathrm{O}(0.12 \mathrm{~g}, 0.50 \mathrm{mmol})$ and $\mathrm{NaO} t \mathrm{Bu}(0.052 \mathrm{~g}, 0.53 \mathrm{mmol})$ were added, and then stirred vigorously at $50{ }^{\circ} \mathrm{C}$ for $12 \mathrm{~h}$. The resulting red suspension was allowed to cool, and the volatiles removed in vacuo. The red residue was then washed with diethylether $(3 \mathrm{x}$ 
$10 \mathrm{~mL})$ and ethanol $(3 \times 10 \mathrm{~mL})$. Isolated yield $=0.221 \mathrm{~g}(89 \%) .{ }^{1} \mathrm{H} \mathrm{NMR}\left(\mathrm{CDCl}_{3}, 500 \mathrm{MHz}, 22\right.$ $\left.{ }^{\circ} \mathrm{C}\right): \delta 9.10\left(\mathrm{~s}, 2 \mathrm{H}, \mathrm{C}_{\mathrm{Ar}}-\mathrm{H}\right), 8.43\left(\mathrm{~d}, 2 \mathrm{H}, J_{\mathrm{HH}}=8.3 \mathrm{~Hz}, \mathrm{C}_{\mathrm{Ar}}-\mathrm{H}\right), 8.00\left(\mathrm{~d}, 2 \mathrm{H}, J_{\mathrm{HH}}=8.1 \mathrm{~Hz}, \mathrm{C}_{\mathrm{Ar}}-\mathrm{H}\right)$, 7.92-7.81 (m, 2H, $\left.\mathrm{C}_{\mathrm{Ar}}-\mathrm{H}\right), 7.65\left(\operatorname{app~t}, 2 \mathrm{H}, J_{\mathrm{HH}}=7.5 \mathrm{~Hz}, \mathrm{C}_{\mathrm{Ar}}-\mathrm{H}\right), 7.48\left(\mathrm{~s}, 2 \mathrm{H}, \mathrm{C}_{\mathrm{Ar}}-\mathrm{H}\right), 7.36(\mathrm{~s}, 2 \mathrm{H}$, $\left.\mathrm{C}_{\mathrm{Ar}}-\mathrm{H}\right), 2.60 \mathrm{ppm}\left(\mathrm{s}, 6 \mathrm{H}, \mathrm{CH}_{3}\right) \cdot{ }^{13} \mathrm{C}\left\{{ }^{1} \mathrm{H}\right\} \mathrm{NMR}\left(\mathrm{CDCl}_{3}, 500 \mathrm{MHz}, 22{ }^{\circ} \mathrm{C}\right): \delta 154.0\left(\mathrm{C}_{\mathrm{Ar}} \mathrm{H}\right), 139.9$ $\left(\mathrm{C}_{\mathrm{Ar}} \mathrm{H}\right), 133.0\left(\mathrm{C}_{\mathrm{Ar}}\right), 132.6\left(\mathrm{C}_{\mathrm{Ar}} \mathrm{H}\right), 130.0\left(\mathrm{C}_{\mathrm{Ar}} \mathrm{H}\right), 127.8\left(\mathrm{C}_{\mathrm{Ar}} \mathrm{H}\right), 126.3\left(\mathrm{C}_{\mathrm{Ar}}\right), 125.6\left(\mathrm{C}_{\mathrm{Ar}} \mathrm{H}\right), 122.4$ $\left(\mathrm{C}_{\mathrm{Ar}} \mathrm{H}\right), 116.24\left(\mathrm{C}_{\mathrm{Ar}}\right), 113.3\left(\mathrm{C}_{\mathrm{Ar}}\right), 109.2\left(\mathrm{C}_{\mathrm{Ar}} \mathrm{H}\right), 107.1\left(\mathrm{C}_{\mathrm{Ar}} \mathrm{H}\right), 23.0 \mathrm{ppm}\left(\mathrm{CH}_{3}\right)$. UV-Vis (DMF): $\lambda$ (ع) 265 (22 300), 274 (sh), 319 (13 600), 339 (11 250), 358 (7 500), 398 (sh), 498 nm (4 100 $\mathrm{M}^{-1} \mathrm{~cm}^{-1}$ ). Anal. Calcd for $\mathrm{C}_{28} \mathrm{H}_{20} \mathrm{~N}_{3} \mathrm{NiCl}: \mathrm{C}, 68.27 ; \mathrm{H}, 4.09$. Found: C, 68.28; H, 4.11.

Synthesis of (Me-Phen NNN $\left.{ }^{\text {Phen-Me }}\right) \mathbf{P d C l}$ (3-Pd): To a stirred solution of $\mathbf{L 3}(0.22 \mathrm{~g}, 0.55 \mathrm{mmol})$ in THF $(10 \mathrm{~mL}), \mathrm{Pd}(\mathrm{COD}) \mathrm{Cl}_{2}(0.14 \mathrm{~g}, 0.50 \mathrm{mmol})$, and $\mathrm{NaO} t \mathrm{Bu}(0.050 \mathrm{~g}, 0.53 \mathrm{mmol})$ were added, and the mixture stirred vigorously at $70{ }^{\circ} \mathrm{C}$ for $12 \mathrm{~h}$. The resulting red suspension was allowed to cool, and the volatiles removed in vacuo. The red residue was then washed with diethylether $(3 \times 10 \mathrm{~mL})$ and ethanol $(3 \times 10 \mathrm{~mL})$. Isolated yield $=0.211 \mathrm{~g}(78 \%) .{ }^{1} \mathrm{H}$ NMR $\left(\mathrm{CDCl}_{3}, 500 \mathrm{MHz}, 22^{\circ} \mathrm{C}\right): \delta 9.38\left(\mathrm{~s}, 2 \mathrm{H}, \mathrm{C}_{\mathrm{Ar}}-\mathrm{H}\right), 8.50\left(\mathrm{~d}, 2 \mathrm{H}, J_{\mathrm{HH}}=8.3 \mathrm{~Hz}, \mathrm{C}_{\mathrm{Ar}}-\mathrm{H}\right), 8.08(\mathrm{~d}, 2 \mathrm{H}$, $\left.J_{\mathrm{HH}}=7.9 \mathrm{~Hz}, \mathrm{C}_{\mathrm{Ar}}-\mathrm{H}\right), 7.94-7.87\left(\mathrm{~m}, 2 \mathrm{H}, \mathrm{C}_{\mathrm{Ar}}-\mathrm{H}\right), 7.72\left(\operatorname{app~t}, 2 \mathrm{H}, J_{\mathrm{HH}}=7.4 \mathrm{~Hz}, \mathrm{C}_{\mathrm{Ar}}-\mathrm{H}\right), 7.67(\mathrm{~s}$, 2H, $\left.\mathrm{C}_{\mathrm{Ar}}-\mathrm{H}\right), 7.53\left(\mathrm{~s}, 2 \mathrm{H}, \mathrm{C}_{\mathrm{Ar}}-\mathrm{H}\right), 2.66 \mathrm{ppm}\left(\mathrm{s}, 6 \mathrm{H}, \mathrm{CH}_{3}\right) .{ }^{13} \mathrm{C}\left\{{ }^{1} \mathrm{H}\right\}$ NMR $\left(\mathrm{CDCl}_{3}, 500 \mathrm{MHz}, 22\right.$ $\left.{ }^{\circ} \mathrm{C}\right): \delta 151.8\left(\mathrm{C}_{\mathrm{Ar}} \mathrm{H}\right), 132.8\left(\mathrm{C}_{\mathrm{Ar}} \mathrm{H}\right), 130.0\left(\mathrm{C}_{\mathrm{Ar}} \mathrm{H}\right), 128.2\left(\mathrm{C}_{\mathrm{Ar}} \mathrm{H}\right), 122.7\left(\mathrm{C}_{\mathrm{Ar}} \mathrm{H}\right), 22.9 \mathrm{ppm}\left(\mathrm{CH}_{3}\right)$. The poor solubility of 3-Pd precluded assignment of all peaks in the ${ }^{13} \mathrm{C}\left\{{ }^{1} \mathrm{H}\right\}$ NMR spectrum. UV-Vis (DMF): $\lambda$ (ع) 266 (31 350), 318(16 200), 335 (10 550), 397 (3 800), 496 nm (5 $350 \mathrm{M}^{-}$ $\left.{ }^{1} \mathrm{~cm}^{-1}\right)$. Anal. Calcd for $\mathrm{C}_{28} \mathrm{H}_{20} \mathrm{~N}_{3} \mathrm{PdCl} \bullet\left(\mathrm{CHCl}_{3}\right)$ : C, 52.80; H, 3.21. Found: C, 52.72; H, 3.01 . 
Synthesis of (Me-Phen NNN ${ }^{\text {Phen-Me })}$ PtCl (3-Pt): To a stirred solution of compound $(0.22 \mathrm{~g}, 0.55$ $\mathrm{mmol})$ in THF $(10 \mathrm{~mL}), \mathrm{Pt}(\mathrm{COD}) \mathrm{Cl}_{2}(0.14 \mathrm{~g}, 0.5 \mathrm{mmol})$, and $\mathrm{NaO} t \mathrm{Bu}(0.050 \mathrm{~g}, 0.53 \mathrm{mmol})$ were added, and the mixture stirred vigorously at $70{ }^{\circ} \mathrm{C}$ for $12 \mathrm{~h}$. The resulting red suspension was allowed to cool, and the volatiles removed in vacuo. The red residue was washed with diethylether (3 x $10 \mathrm{~mL})$ and acetonitrile $(3 \times 10 \mathrm{~mL})$. Solubility of the 3-Pt was generally poor in all organic solvents. Isolated yield $=0.226 \mathrm{~g}(65 \%) .{ }^{1} \mathrm{H} \mathrm{NMR}\left(\mathrm{CDCl}_{3}, 300 \mathrm{MHz}, 22{ }^{\circ} \mathrm{C}\right): \delta$ $9.58\left(\mathrm{~s}, 2 \mathrm{H}, \mathrm{C}_{\mathrm{Ar}}-\mathrm{H}\right), 8.45\left(\mathrm{~d}, 2 \mathrm{H}, J_{\mathrm{HH}}=8.3 \mathrm{~Hz}, \mathrm{C}_{\mathrm{Ar}}-\mathrm{H}\right), 8.07\left(\mathrm{~d}, 2 \mathrm{H}, J_{\mathrm{HH}}=7.9 \mathrm{~Hz}, \mathrm{C}_{\mathrm{Ar}}-\mathrm{H}\right), 7.93-$ $7.86\left(\mathrm{~m}, 2 \mathrm{H}, \mathrm{C}_{\mathrm{Ar}}-\mathrm{H}\right), 7.77-7.60$ (overlapped m, 4H, $\left.\mathrm{C}_{\mathrm{Ar}}-\mathrm{H}\right), 7.47\left(\mathrm{~s}, 2 \mathrm{H}, \mathrm{C}_{\mathrm{Ar}}-\mathrm{H}\right), 2.65 \mathrm{ppm}(\mathrm{s}, 6 \mathrm{H}$, $\left.\mathrm{CH}_{3}\right) .{ }^{13} \mathrm{C}\left\{{ }^{1} \mathrm{H}\right\}$ NMR $\left(\mathrm{CDCl}_{3}, 500 \mathrm{MHz}, 22{ }^{\circ} \mathrm{C}\right): \delta 151.0\left(\mathrm{C}_{\mathrm{Ar}} \mathrm{H}\right), 140.0\left(\mathrm{C}_{\mathrm{Ar}} \mathrm{H}\right), 132.7\left(\mathrm{C}_{\mathrm{Ar}} \mathrm{H}\right)$, $129.9\left(\mathrm{C}_{\mathrm{Ar}} \mathrm{H}\right), 128.3\left(\mathrm{C}_{\mathrm{Ar}} \mathrm{H}\right), 126.2\left(\mathrm{C}_{\mathrm{Ar}} \mathrm{H}\right), 122.7\left(\mathrm{C}_{\mathrm{Ar}} \mathrm{H}\right), 22.9 \mathrm{ppm}\left(\mathrm{CH}_{3}\right)$. Six aromatic carbon signals could not be assigned in the ${ }^{13} \mathrm{C}$ NMR spectrum due poor solubility. Anal. Calcd for $\mathrm{C}_{28} \mathrm{H}_{20} \mathrm{~N}_{3} \mathrm{PtCl}: \mathrm{C}, 53.47 ; \mathrm{H}, 3.20$. Found: C, 52.83; H, 3.31 .

\section{Computational Details}

All calculations were carried out using the Gaussian 09 program package ${ }^{41}$ Initial geometries were taken from X-ray crystallographic data and were optimized with M06/6-31+G(d,p) method. Vibrational frequencies were computed at the same level to identify structures as energy minimum or transition state structures and to evaluate zero-point vibrational energies (ZPVE) and thermal energies at $298 \mathrm{~K}$. Solvation effects $\left(\mathrm{CH}_{2} \mathrm{Cl}_{2}\right)$ were modeled using the SMD approach. SMD-TDDFT calculations were conducted using M06/6-31+G(d,p) with solvent equilibration. The first 50 states were considered in all SMD-TDDFT calculations to cover UV and visible range of the spectrum. 


\section{ASSOCIATED CONTENT}

Supporting Information. Experimental details of optimization of cross-coupling routes to 4-Br, 4-NO $\mathrm{N}_{2}, \mathrm{L2}$ and L3; multi-nuclear NMR spectra of all new compounds; details of X-ray crystallography experiments; details of computational methods; combined crystallographic information file containing all X-ray data. CCDC 1526650-1526657 contain the supplementary crystallographic data for this paper. The data can be obtained free of charge from The Cambridge Crystallographic Data Centre via www.ccdc.cam.ac.uk/structures.

The following files are available free of charge:

Supporting Information File (PDF)

Combined Crystallographic Information File (CIF)

\section{AUTHOR INFORMATION}

\section{Corresponding Author}

*david.herbert@umanitoba.ca

\section{ORCID}

David E. Herbert: 0000-0001-8190-2468

\section{Author Contributions}

The manuscript was written through contributions of all authors. All authors have given approval to the final version of the manuscript.

\section{Funding Sources}


The Natural Sciences and Engineering Research Council is thanked for a Discovery Grant to DEH (RGPIN-2013-03551) and a Canada Graduate Scholarship (PKG). Purchase of an X-Ray diffractometer was possible through support of the Canada Foundation for Innovation and Research Manitoba (\#32146). The University of Manitoba is gratefully acknowledged for startup funding (DEH) and GETS support (PM, PKG).

\section{ACKNOWLEDGMENT}

We are grateful to Prof. Mazdak Khajehpour for access to a UV-Vis spectrometer. Mark Cooper and Prof. Frank Hawthorne are gratefully acknowledged for collection of crystal data for $\mathbf{L} \mathbf{2}$ and 2-Ni.

\section{ABBREVIATIONS}

1,5-COD 1,5-cyclooctadiene; TDDFT time-dependent density functional theory; PCM polarizable continuum model; EtAc ethyl acetate; MO molecular orbitals; dppf (1,1'diphenylphosphino)ferrocene; OAc acetate; $\mathrm{NaO} t \mathrm{Bu}$ sodium tert-butoxide; $\mathrm{NaO} t$ Pen sodium tert-pentoxide; DME 1,2-dimethoxyethane 


\section{REFERENCES}

[1] (a) Roznyatovskiy, V. V.; Lee, C.-H.; Sessler, J. L. $\pi$-Extended Isomeric and Expanded Porphyrins. Chem. Soc. Rev. 2013, 42, 1921-1933; (b) Flamigni, L.; Encinas, S.; Barigelletti, F.; MacDonnell, F. M.; Kim, K.-J.; Puntoriero, F.; Campagna, S. Excited-State Interconversion Between Emissive MLCT Levels in a Dinuclear Ru(II) Complex Containing a Bridging Ligand with an Extended $\pi$ System. Chem. Commun. 2000, 1185-1186; (c) Hayashi, K.; Nakatani, M.; Hayashi, A.; Takano, M.; Okazaki, M.; Toyota, K.; Yoshifuji, M.; Ozawa, F. Synthesis and Structures of Platinum(0) Alkyne Complexes with Extended $\pi$-Conjugated Systems.

Organometallics 2008, 27, 1970-1972; (d) Hanson, K.; Roskop, L.; Djurovich, P. I.; Zahariev, F.; Gordon, M. S.; Thompson, M. E. A Paradigm for Blue- or Red-Shifted Absorption of Small Molecules Depending on the Site of $\pi$-Extension. J. Am. Chem. Soc. 2010, 132, 16247-16255;

(e) Hussain, M.; El-Shafei, A.; Islam, A.; Han, L. Structure-Property Relationship of Extended $\pi$ Conjugation of Ancillary Ligands with and without an Electron Donor of Heteroleptic Ru(II) Bipyridyl Complexes for High Efficiency Dye-Sensitized Solar Cells. Phys. Chem. Chem. Phys. 2013, 15, 8401-8408; (f) Li, Z; Sun, W. Synthesis, Photophysics, and Reverse Saturable Absorption of Platinum Complexes Bearing Extended $\pi$-Conjugated CNN Ligands. Dalton Trans. 2013, 42, 14021-14029; (g) He, M.; Ji, Z.; Huang, Z.; Wu, Y. Molecular Orbital Engineering of a Panchromatic Cyclometalated Ru(II) Dye for p-Type Dye-Sensitized Solar Cells. J. Phys. Chem. C 2014, 118, 16518-16525; (h) Li, Z.; Cui, P.; Wang, C.; Kilina, S.; Sun, W. Nonlinear Absorbing Cationic Bipyridyl Iridium(III) Complexes Bearing Cyclometalating Ligands with Different Degrees of $\pi$-Conjugation: Synthesis, Photophysics, and Reverse Saturable Absorption. J. Phys. Chem. C 2014, 118, 28764-28775; (i) Ozawa, H.; Fukushima, K.; Urayama, A.; Arakawa, H. Efficient Ruthenium Sensitizer with an Extended $\pi$-Conjugated 
Terpyridine Ligand for Dye-Sensitized Solar Cells. Inorg. Chem. 2015, 54, 8887-8889; (j) Kuramochi, Y.; Ishitani, O. Iridium(III) 1-Phenylisoquinoline Complexes as a Photosensitizer for Photocatalytic $\mathrm{CO}_{2}$ Reduction: A Mixed System with a $\mathrm{Re}(\mathrm{I})$ Catalyst and a Supramolecular Photocatalyst. Inorg. Chem. 2016, 55, 5702-5709; (k) Fuertes, S.; Chueca, A. J.; Peralvarez, M.; Borja, P.; Torrell, M.; Carreras, J.; Sicilia, V. White Light Emission from Planar Remote Phosphor Based on NHC Cycloplatinated Complexes. ACS Appl. Mater. Interfaces 2016, 8, 16160-16169.

[2] (a) Kappaun, S.; Rentenberger, S.; Pogantsch, A.; Zojer, E.; Mereiter, K.; Trimmel, G.; Saf, R.; Moeller, K. C.; Stelzer, F.; Slugovc, C. Organoboron Quinolinolates with Extended Conjugated Chromophores: Synthesis, Structure, and Electronic and Electroluminescent Properties. Chem. Mater. 2006, 18, 3539-3547; (b) Kiprof, P.; Carlson, J. C.; Anderson, D. R.; Nemykin, V. N. Systematic Color Tuning of a Family of Luminescent Azole-Based Organoboron Compounds Suitable for OLED Applications. Dalton Trans. 2013, 42, 1512015132; (c) Barbon, S. M.; Staroverov, V. N.; Gilroy, J. B. Effect of Extended $\pi$ Conjugation on the Spectroscopic and Electrochemical Properties of Boron Difluoride Formazanate Complexes J. Org. Chem. 2015, 80, 5226-5235; (d) Yamazawa, S.; Nakashima, M.; Suda, Y.; Nishiyabu, R.; Kubo, Y. 2,3-Naphtho-Fused BODIPYs as Near-Infrared Absorbing Dyes. J. Org. Chem. 2016, $81,1310-1315$.

[3] Chelucci, G.; Thummel, R. P. Chiral 2,2'-Bipyridines, 1,10-Phenanthrolines, and 2,2':6',2"Terpyridines: Syntheses and Applications in Asymmetric Homogeneous Catalysis. Chem. Rev. 2002, 102, 3129-3170. 
[4] Gunanathan, C.; Gnanaprakasam, B.; Iron, M. A.; Shimon, L. J. W.; Milstein, D. "LongRange" Metal-Ligand Cooperation in $\mathrm{H}_{2}$ Activation and Ammonia-Promoted Hydride Transfer with a Ruthenium-Acridine Pincer Complex. J. Am. Chem. Soc. 2010, 132, 14763-14765.

[5] Neufeldt, S. R.; Sanford, M. S. Controlling Site Selectivity in Palladium-Catalyzed C-H Bond Functionalization. Acc. Chem. Res. 2012, 45, 936-946.

[6] Krichevsky, O; Bonnet, G. Fluorescence Correlation Spectroscopy: the Technique and its Applications. Rep. Prog. Phys. 2002, 65, 251-297.

[7] Tumir, L.-M.; Stojkovic, M. R.; Piantanida, I. Come-back of Phenanthridine and Phenanthridinium Derivatives in the $21^{\text {st }}$ Century. Beilstein J. Org. Chem. 2014, 10, 2930-2954, $25 \mathrm{pp}$.

[8] Park, G. Y.; Wilson, J. J.; Song, Y.; Lippard, S. J. Phenanthriplatin, a Monofunctional DNABinding Platinum Anticancer Drug Candidate with Unusual Potency and Cellular Activity Profile. Proc. Natl. Acad. Sci. 2012, 109, 11987-11992.

[9] (a) Lu, L.-Q.; Li, Y.; Junge, K.; Beller, M. Iron-Catalyzed Hydrogenation for the In Situ Regeneration of an NAD(P)H Model: Biomimetic Reduction of $\alpha$-Keto-/ $\alpha$-Iminoesters. Angew . Chem., Int. Ed. 2013, 52, 8382-8386; (b) Chen, Q.-A.; Gao, K.; Duan, Y.; Ye, Z.-S.; Shi, L.; Yang, Y.; Zhou, Y.-G. Dihydrophenanthridine: A New and Easily Regenerable NAD(P)H Model for Biomimetic Asymmetric Hydrogenation. J. Am. Chem. Soc. 2012, 134, 2442-2448.

[10] (a) Kido, J.; Endo, J. A Novel Electroluminescent Metal Complex: Tris(4phenanthridinolato)aluminum(III). Chem. Lett. 1997, 593-594; (b) Fukase, A.; Kido, J. Organic 
Electroluminescent Devices Having Self-doped Cathode Interface Layer. Jpn. J. Appl. Phys., Part 2 2002, 41, L334-L336.

[11] Valk, J.-M.; Claridge, T. D. W.; Brown, J. M.; Hibbs, D.; Hursthouse, M. B. Synthesis and Chemistry of a New P-N Chelating Ligand: $(R)$ - and (S)-6-(2'-diphenylphosphino-1'naphthyl)phenanthridine. Tetrahedron: Asymmetry 1995, 6, 2597-610.

[12] Raszeja, L.; Maghnouj, A.; Hahn, S.; Metzler-Nolte, N. A Novel Organometallic ReI Complex with Favourable Properties for Bioimaging and Applicability in Solid-Phase Peptide Synthesis. ChemBioChem 2011, 12, 371-376.

[13] Sicilia, V.; Fuertes, S.; Martin, A.; Palacios, A. N-Assisted CPh-H Activation in 3,8Dinitro-6-phenylphenanthridine. New C,N-Cyclometalated Compounds of Platinum(II): Synthesis, Structure, and Luminescence Studies. Organometallics 2013, 32, 4092-4102.

[14] Jiang, B.; Gu, Y.; Qin, J.; Ning, X.; Gong, S.; Xie, G.; Yang, C. Deep-Red Iridium(III) Complexes Cyclometalated by Phenanthridine Derivatives for Highly Efficient SolutionProcessed Organic Light-Emitting Diodes. J. Mater. Chem. C 2016, 4, 3492-3498.

[15] Mondal, R.; Giesbrecht, P. K.; Herbert, D. E. Nickel(II), Copper(I) and Zinc(II) Complexes Supported by a (4-diphenylphosphino)phenanthridine Ligand. Polyhedron 2016, 108, 156-162.

[16] (a) Jensen, K. A.; Nielsen, P. H. Chelates with Heterocyclic Ligands. I. Chelates Derived from $N, N^{\prime}$-Bis(8-quinolyl)ethylenediamine and Analogous Compounds. Acta Chem. Scand. 1964, 18, 1-10; (b) Puzas, J. P.; Nakon, R.; Petersen, J. L. Direct Evidence for an SN1CB Mechanism. 4. Crystal and Molecular Structure of Chloro(bis(8-quinolinyl)amidoN1,N2,N3)copper(II), a Metal Chelate Containing an $\mathrm{sp}^{2}$-Hybridized Deprotonated Amine. 
Inorg. Chem. 1986, 25, 3837-40; (c) Peters, J. C.; Harkins, S. B.; Brown, S. D.; Day, M. W. Pincer-like Amido Complexes of Platinum, Palladium, and Nickel. Inorg. Chem. 2001, 40, 50835091; (d) Maiti, D.; Paul, H.; Chanda, N.; Chakraborty, S.; Mondal, B.; Puranik, V. G.; Lahiri, G. K. Synthesis, Structure, Spectral and Electron-Transfer Properties of Octahedral$\left[\mathrm{Co}^{\mathrm{III}}(\mathrm{L})_{2}\right]^{+} /\left[\mathrm{Zn}^{\mathrm{II}}(\mathrm{L})_{2}\right]$ and Square Planar- $\left[\mathrm{Cu}^{\mathrm{II}}(\mathrm{L})\left\{\mathrm{OC}(=\mathrm{O}) \mathrm{CH}_{3}\right\}\right]$ Complexes Incorporating Anionic Form of Tridentate Bis(8-quinolinyl)amine Ligand. Polyhedron 2004, 23, 831-840.

[17] (a) Chase, P. A.; van Koten, G., Nitrogen-Based Pincers: A Versatile Platform for Organometallic Chemistry. In The Chemistry of Pincer Compounds, Jensen, C. M., Ed. Elsevier Science B.V.: Amsterdam, 2007; pp 181-233; (b) Gade, L. H.; Melen, R. L., New Chemistry with Anionic NNN Pincer Ligands. In The Privileged Pincer-Metal Platform: Coordination Chemistry \& Applications, van Koten, G.; Gossage, R. A., Eds. Springer International Publishing: New York, 2016; Vol. 54, pp 179-208.

[18] Ruiz-Castillo, P.; Buchwald, S. L. Applications of Palladium-Catalyzed C-N CrossCoupling Reactions. Chem. Rev. 2016, 116, 12564-12649.

[19] Tummatorn, J.; Krajangsri, S.; Norseeda, K.; Thongsornkleeb, C.; Ruchirawat, S. A New Synthetic Approach to 6-Unsubstituted Phenanthridine and Phenanthridine-like Compounds Under Mild and Metal-Free Conditions. Org. Biomol. Chem. 2014, 12, 5077-5081.

[20] Maksić, Z. B.; Barić, D.; Müller, T. Clar's Sextet Rule Is a Consequence of the $\sigma$-Electron Framework. J. Phys. Chem. A 2006, 110, 10135-10147. 
[21] Macrae, C. F.; Edgington, P. R.; McCabe, P.; Pidcock, E.; Shields, G. P.; Taylor, R.; Towler, M.; van de Streek, J. Mercury: Visualization and Analysis of Crystal Structures. J. Appl. Cryst. 2006, 39, 453-457.

[22] Betley, T. A.; Qian, B. A.; Peters, J. C. Group VIII Coordination Chemistry of a PincerType Bis(8-quinolinyl)amido Ligand. Inorg. Chem. 2008, 47, 11570-11582.

[23] Harkins, S. B.; Peters, J. C. Unexpected Photoisomerization of a Pincer-type Amido Ligand Leads to Facial Coordination at Pt(IV). Inorg. Chem. 2006, 45, 4316-4318.

[24] Testa, A. C. The N-B Vibrational Frequency in Complexes of Aromatic Azines with $\mathrm{BCl}_{3}$. Spectrochim. Acta, Part A 1999, 55A, 299-309.

[25] Johnstone, T. C.; Lippard, S. J. The Chiral Potential of Phenanthriplatin and Its Influence on Guanine Binding. J. Am. Chem. Soc. 2014, 136, 2126-2134.

[26] Norek, M.; Dresner, J.; Prochorow, J. Spectroscopy and Photophysics of Monoazaphenanthrenes. I. Absorption and Fluorescence Spectra of Phenanthridine and 7,8Benzoquinoline. Acta Phys. Pol., A 2003, 104, 425-439.

[27] Sutherland, D.; Compton, C. The Absorption Spectra of Some Substituted Quinolines and Their Methiodides. J. Org. Chem. 1952, 17, 1257-1261.

[28] (a) Slattery, D. K.; Linkous, C. A.; Gruhn, N. E.; Baum, J. C. Semiempirical MO and Voltammetric Estimation of Ionization Potentials of Organic Pigments. Comparison to Gas Phase Ultraviolet Photoelectron Spectroscopy. Dyes Pigm. 2001, 49, 21-27; (b) D'Andrade, B. W.; Datta, S.; Forrest, S. R.; Djurovich, P.; Polikarpov, E.; Thompson, M. E. Relationship Between the Ionization and Oxidation Potentials of Molecular Organic Semiconductors. Org. 
Electron. 2005, 6, 11-20; (c) Djurovich, P. I.; Mayo, E. I.; Forrest, S. R.; Thompson, M. E. Measurement of the Lowest Unoccupied Molecular Orbital Energies of Molecular Organic Semiconductors. Org. Electron. 2009, 10, 515-520.

[29] Wopschall, R. H.; Shain, I. Effects of Adsorption of Electroactive Species in Stationary Electrode Polarography. Anal. Chem. 1967, 39, 1514-1527.

[30] Davidson, J. J.; DeMott, J. C.; Douvris, C.; Fafard, C. M.; Bhuvanesh, N.; Chen, C.-H.; Herbert, D. E.; Lee, C.-I.; McCulloch, B. J.; Foxman, B. M.; Ozerov, O. V. Comparison of the Electronic Properties of Diarylamido-Based PNZ Pincer Ligands: Redox Activity at the Ligand and Donor Ability Toward the Metal. Inorg. Chem. 2015, 54, 2916-2935.

[31] Yan, L.; Zhao, D.; Lan, J.; Cheng, Y.; Guo, Q.; Li, X.; Wu, N.; You, J. Palladium-Catalyzed Tandem N-H/C-H Arylation: Regioselective Synthesis of N-Heterocycle-Fused Phenanthridines as Versatile Blue-emitting Luminophores. Org. Biomol. Chem. 2013, 11, 7966-7977.

[32] Bossi, A.; Rausch, A. F.; Leitl, M. J.; Czerwieniec, R.; Whited, M. T.; Djurovich, P. I.; Yersin, H.; Thompson, M. E. Photophysical Properties of Cyclometalated Pt(II) Complexes: Counterintuitive Blue Shift in Emission with an Expanded Ligand $\pi$ System. Inorg. Chem. 2013, $52,12403-12415$.

[33] (a) Zhao, Y.; Truhlar, D. G. The M06 Suite of Density Functionals for Main Group Thermochemistry, Thermochemical Kinetics, Noncovalent Interactions, Excited States, and Transition Elements: Two New Functionals and Systematic Testing of Four M06-Class Functionals and 12 Other Functionals Theor. Chem. Acc. 2008, 120, 215-241; (b) Lee, C.; Yang, W.; Parr, R. G. Development of the Colle-Salvetti Correlation-Energy Formula into a Functional 
of the Electron Density Phys. Rev. B: Condens. Matter 1988, 37, 785-789; (c) Stephens, P. J.; Devlin, F. J.; Chabalowski, C. F.; Frisch, M. J. Ab Initio Calculation of Vibrational Absorption and Circular Dichroism Spectra Using Density Functional Force Fields. J. Phys. Chem. 1994, 98, 11623-11627.

[34] Rogers, J. E.; Nguyen, K. A.; Hufnagle, D. C.; McLean, D. G.; Su, W.; Gossett, K. M.; Burke, A. R.; Vinogradov, S. A.; Pachter, R.; Fleitz, P. A. Observation and Interpretation of Annulated Porphyrins: Studies on the Photophysical Properties of mesoTetraphenylmetalloporphyrins. J. Phys. Chem. A 2003, 107, 11331-11339.

[35] Lee, C.-I.; Zhou, J.; Ozerov, O. V. Catalytic Dehydrogenative Borylation of Terminal Alkynes by a SiNN Pincer Complex of Iridium. J. Am. Chem. Soc. 2013, 135, 3560-3566.

[36] Tsuji, J., Palladium Reagents and Catalysts: New Perspectives for the 21st Century. Hoboken, NJ : Wiley: Hoboken, NJ, 2004.

[37] Fulmer, G. R.; Miller, A. J. M.; Sherden, N. H.; Gottlieb, H. E.; Nudelman, A.; Stoltz, B. M.; Bercaw, J. E.; Goldberg, K. I. NMR Chemical Shifts of Trace Impurities: Common Laboratory Solvents, Organics, and Gases in Deuterated Solvents Relevant to the Organometallic Chemist. Organometallics 2010, 29, 2176-2179.

[38] Connelly, N. G.; Geiger, W. E. Chemical Redox Agents for Organometallic Chemistry. Chem. Rev. 1996, 96, 877-910.

[39] Guthrie, D. B.; Curran, D. P. Asymmetric Radical and Anionic Cyclizations of Axially Chiral Carbamates. Org. Lett. 2009, 11, 249-251. 
[40] Van Rossom, W.; Asby, D. J.; Tavassoli, A.; Gale, P. A. Perenosins: A New Class of Anion Transporter with Anti-Cancer Activity. Org. Biomol. Chem. 2016, 14, 2645-2650.

[41] Frisch, M. J.; Trucks, G. W.; Schlegel, H. B.; Scuseria, G. E.; Robb, M. A.; Cheeseman, J. R.; Scalmani, G.; Barone, V.; Mennucci, B.; Petersson, G. A.; Gaussian 09, revision A. 2; Gaussian, Inc.: Wallingford, CT, 2009, (see SI for full reference). 


\section{FOR TABLE OF CONTENTS ONLY}

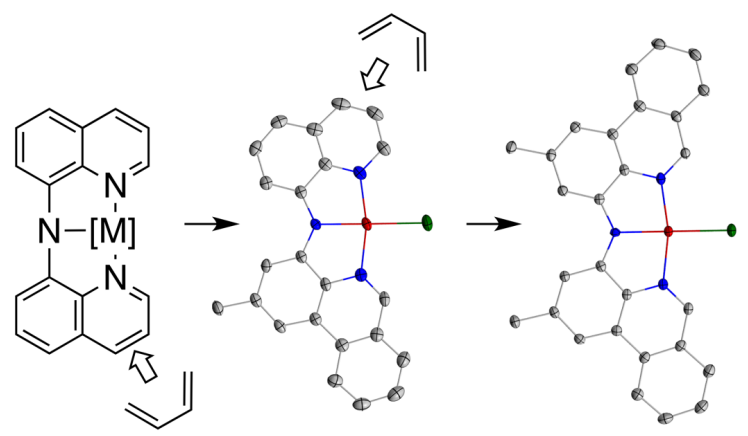

A series of tridentate ligands containing phenanthridinyl (3,4-benzoquinolinyl) units are presented, providing a template for exploring systematic $\pi$-extension in pincer-like amido complexes of Group 10 metals. Unlike related benzannulated complexes, extending conjugation did not significantly impact the energy of the lowest energy absorption $\left(\lambda_{\max }\right)$ of the metal complexes. TD-DFT revealed that benzannulation changes the orbital contributions to $\lambda_{\max }$, with an increasingly important role for the HOMO to LUMO+1 transition with extended conjugation. 